Article

\title{
Taxonomic and Metabolite Diversities of Moss-Associated Actinobacteria from Thailand
}

\author{
Chadabhorn Insuk ${ }^{1}$ (D), Pornkanok Pongpamorn ${ }^{2}$ (D), Adrian Forsythe ${ }^{1}$ (D) Atsuko Matsumoto ${ }^{3}$, Satoshi Ōmura ${ }^{3}$, \\ Wasu Pathom-aree ${ }^{4, *}$, Naowarat Cheeptham ${ }^{5, *(1)}$ and Jianping $\mathrm{Xu}{ }^{1, *(\mathbb{C})}$
}

1 Department of Biology, McMaster University, Hamilton, ON L8S 4K1, Canada; insukc@mcmaster.ca (C.I.); forsytae@mcmaster.ca (A.F.)

2 National Omics Center, National Science and Technology Development Agency (NSTDA), Pathum Thani 12120, Thailand; pornkanok.pon@nstda.or.th

3 Kitasato Institute for Life Sciences, Kitasato University, Minato-ku, Tokyo 108-8641, Japan; amatsu@lisci.kitasato-u.ac.jp (A.M.); omuras@insti.kitasato-u.ac.jp (S.Ō.)

4 Research Center of Microbial Diversity and Sustainable Utilization, Faculty of Science, Chiang Mai University, Chiang Mai 50200, Thailand

5 Department of Biological Sciences, Faculty of Science, Thompson Rivers University, Kamloops, BC V2C 0C8, Canada

* Correspondence: wasu.p@cmu.ac.th (W.P.-a.); ncheeptham@tru.ca (N.C.); jpxu@mcmaster.ca (J.X.)

check for

updates

Citation: Insuk, C.; Pongpamorn, P.; Forsythe, A.; Matsumoto, A.; Ōmura, S.; Pathom-aree, W.; Cheeptham, N.; $\mathrm{Xu}, \mathrm{J}$. Taxonomic and Metabolite Diversities of Moss-Associated Actinobacteria from Thailand. Metabolites 2022, 12, 22. https:// doi.org/10.3390/metabo12010022

Academic Editors: Nicole van Dam and Remington X. Poulin

Received: 11 November 2021 Accepted: 25 December 2021 Published: 27 December 2021

Publisher's Note: MDPI stays neutral with regard to jurisdictional claims in published maps and institutional affiliations.

Copyright: (C) 2021 by the authors. Licensee MDPI, Basel, Switzerland. This article is an open access article distributed under the terms and conditions of the Creative Commons Attribution (CC BY) license (https:// creativecommons.org/licenses/by/ $4.0 /)$.

\begin{abstract}
Actinobacteria are a group of ecologically important bacteria capable of producing diverse bioactive compounds. However, much remains unknown about the taxonomic and metabolic diversities of actinobacteria from many geographic regions and ecological niches. In this study, we report the isolation of actinobacteria from moss and moss-associated rhizosphere soils in Thailand. Among the 89 isolates analyzed for their bioactivities, 86 strains produced indole-3-acetic acid (IAA, ranging from 0.04 to $59.12 \mathrm{mg} / \mathrm{L}) ; 42$ strains produced hydroxamate type of siderophore; 35 strains produced catecholate type of siderophore; 21 strains solubilized tricalcium phosphate; and many strains exhibited antagonistic activities against one to several of the seven selected plant, animal, and human pathogens. Overall, actinobacteria from the rhizosphere soil of mosses showed greater abilities to produce IAA and siderophores and to solubilize tricalcium phosphate than those from mosses. Among these 89 isolates, 37 were analyzed for their 16S rRNA gene sequences, which revealed their diverse phylogenetic distributions among seven genera, Streptomyces, Micromonospora, Nocardia, Actinoplanes, Saccharothrix, Streptosporangium, and Cryptosporangium. Furthermore, gas chromatography-mass spectrometry analyses of ethyl acetate crude extracts of three selected isolates with inhibitory effects against a methicillin-resistant Staphylococcus aureus strain revealed diverse metabolites with known antimicrobial activities. Together, our results demonstrate that actinobacteria from mosses in Thailand are taxonomically diverse and capable of producing a range of metabolites with plant-growth-promoting and microbial pathogen-inhibiting potentials.
\end{abstract}

Keywords: actinobacteria; moss; selective isolation; plant growth promotion; MRSA (methicillinresistant Staphylococcus aureus); white-nose syndrome; VOCs (volatile organic compounds); GC-MS (gas chromatography-mass spectrometry)

\section{Introduction}

Plant-associated microorganisms have shown an outstanding ability to produce compounds of high therapeutic value [1]. Among all bacterial taxa associated with plants, Actinobacteria, a phylum of Gram-positive, high GC-content bacteria, are among the most prolific producers of secondary metabolites, especially antibiotics. Actinobacteria are common components of endophytic microbiota of medicinal plants $[2,3]$ and have been found in the rhizosphere of numerous plants, including crops, such as wheat [4], yam [5], and pea [6]. These plant-associated actinobacteria can employ several mechanisms to influence 
plant growth, such as enhancing nitrogen fixation, phosphate solubilization, iron acquisition through secreting siderophores, and production of phytohormones [7]. They can also protect plants by inhibiting plant pathogens [8], enhancing abiotic stress tolerance [9,10], and maintaining overall soil health [11]. However, most of our understandings regarding plant-associated actinobacteria have come from studies in higher plants. The investigation of actinobacteria from lower plants, such as bryophytes (including mosses), and their beneficial traits are still rare. Recently, a member of the actinobacteria genus Micromonospora was reported from bryophytes, which showed plant growth-promoting activity in vitro and in planta [12]. Such a result suggests a potentially important role of actinobacteria in mosses.

Mosses are a group of early-diverging land plants that naturally exhibit high tolerance to extreme desiccation and can return to their normal metabolism very rapidly after rehydration. Microorganisms associated with mosses likely experience similar stress conditions [13]. Ecologically, mosses are found in a variety of ecosystems, such as on the ground, tree trunks, or even human-made concrete surfaces. They play important roles in food web dynamics, carbon and nutrient cycling, and soil temperature and moisture regulations [14]. Previous research has shown that moss-associated microbes are capable of enhancing the growth of the moss Physcomitrium sphaericum during its acclimatization from the laboratory environment to natural field soil [12], fix $\mathrm{N}_{2}$ in the air [15], and contribute to the process of biomass decomposition [16].

In this study, we hypothesized that actinobacteria from mosses from Thailand are diverse and capable of producing both plant growth-promoting metabolites as well as antibiotics effective against diverse pathogens. To test their potential productions of antimicrobial compounds, we selected several representative pathogens of global significance to plants, animals, and humans. For plant pathogens, we choose Pseudomonas syringae pv. syringae and Pseudomonas aeruginosa for testing. Pseudomonas syringae is a globally distributed plant pathogenic bacterium that can cause diseases in monocotyledon, herbaceous dicotyledon, and woody dicotyledon plants [17-20]. There are more than 60 pathovars of $P$. syringae, but the most polyphagous one is $P$. syringae $\mathrm{pv}$. syringae with its wide host range and virulence factors [21]. Pseudomonas aeruginosa is an opportunistic pathogen of diverse plants and animals, including humans [22-25]. For the animal pathogen, we choose Pseudogymnoascus destructans, a psychrophilic fungal pathogen and the causative agent of white-nose syndrome (WNS) that has caused significant mortality to hibernating bats in North America [26,27]. For human pathogens, we selected four strains representing three common pathogens for testing: two strains belong to the Gram-positive Staphylococcus aureus and one strain each of the Gram-negative Escherichia coli and the opportunistic yeast pathogen Candida albicans. The E. coli strain was resistant to multiple antibiotics, and one of the two strains of $S$. aureus was resistant to methicillin. We are specifically interested in whether actinobacteria from mosses are capable of inhibiting the growth of diverse human pathogens, including drug-resistant bacterial pathogens. If such activities are found, the actinobacteria from mosses could represent a potential source for novel antibiotics to help combat drug-resistant infections [28].

To achieve our objectives and test our hypothesis, we isolated cultivable actinobacteria associated with various moss species in northern Thailand. The potential taxonomic affiliations of selected isolates were investigated based on their 16S rRNA gene sequences. Their abilities to produce plant-growth promoters and to inhibit the growth of plant pathogens, human pathogens, and bat pathogens were also determined. Studying actinobacteria associated with mosses and their ability to produce bioactive compounds can help us not only understand the interactions between actinobacteria and mosses but also discover potential new bioactive compounds to broaden drug discovery. 


\section{Results}

\subsection{Isolation of Actinobacteria from Mosses}

The total samples used in this study belonged to nine moss species, consisting of Pogonatum microstomum (R. Br. ex Schwägr.) Brid. (No. 3), Hypnum sp. (No. 6), Thuidium cymbifolium (Dozy \& Molk.) Dozy \& Molk. (No. 11), Plagiomnium maximoviczii (Lindb.) T.J. Kop (No. 13), Brachythecium buchananii (Hook.) A. Jaeger (No. 32), Didymodon maschalogena (Renauld \& Cardot) Broth. (No. 33), Macrothamnium submacrocarpum (A. Jaeger ex Renauld \& Cardot) M. Fleisch. (No. 49), Ceratodon purpureus (Hedw.) Brid. (No. 52), and Bryum recurvulum Mitt. (No. 54). The numbers in the parenthesis correspond to the codes of moss samples in the herbarium. These numbers are also used as part of the name for the bacterial isolates from those moss samples. After species identification, the moss samples were dried and kept at Chiang Mai University Herbarium (Herbarium code: CMUB). The geographic coordinates for each of the moss samples are listed in Table 1.

Table 1. Actinobacteria obtained from mosses using two different methods. Method 1 used a pre-treatment temperature of $25^{\circ} \mathrm{C}$; method 2 used a pre-treatment temperature of $60{ }^{\circ} \mathrm{C}$.

\begin{tabular}{|c|c|c|c|c|c|c|}
\hline \multirow{2}{*}{ Method } & \multirow{2}{*}{ Host Moss Species } & \multirow{2}{*}{ Location } & \multirow{2}{*}{$\begin{array}{l}\text { Isolation } \\
\text { Media }\end{array}$} & \multicolumn{2}{|c|}{ Average Value CFU/g } & \multirow{2}{*}{$\begin{array}{c}\text { No. } \\
\text { Isolates }\end{array}$} \\
\hline & & & & Rhizosphere Soil & Inside Moss & \\
\hline \multirow{6}{*}{ Method 1} & \multirow[b]{2}{*}{ P. microstomum } & $8^{\circ} 35^{\prime} 19^{\prime \prime} \mathrm{N}$ & WPA & $1.3 \times 10^{4}$ & 0 & 15 \\
\hline & & $98^{\circ} 29^{\prime} 12^{\prime \prime} \mathrm{E}$ & V8 juice agar & $4.6 \times 10^{4}$ & 0 & 36 \\
\hline & \multirow{2}{*}{ Hурпит sp. } & $8^{\circ} 35^{\prime} 19^{\prime \prime} \mathrm{N}$ & WPA & $5.9 \times 10^{4}$ & 0 & 23 \\
\hline & & $98^{\circ} 29^{\prime} 12^{\prime \prime} \mathrm{E}$ & V8 juice agar & $9.5 \times 10^{3}$ & 0 & 6 \\
\hline & \multirow{2}{*}{ P. maximoviczii } & $8^{\circ} 35^{\prime} 19^{\prime \prime} \mathrm{N}$ & WPA & $1.5 \times 10^{3}$ & $2 \times 10^{3}$ & 3 \\
\hline & & $98^{\circ} 29^{\prime} 12^{\prime \prime} \mathrm{E}$ & V8 juice agar & $4.4 \times 10^{4}$ & $2 \times 10^{3}$ & 0 \\
\hline \multirow{12}{*}{ Method 2} & \multirow{2}{*}{ B. buchananii } & $18^{\circ} 33^{\prime} 14^{\prime \prime} \mathrm{N}$ & WPA & $1.1 \times 10^{4}$ & $4.5 \times 10^{3}$ & 30 \\
\hline & & $98^{\circ} 46^{\prime} 52^{\prime \prime} \mathrm{E}$ & V8 juice agar & $7.5 \times 10^{3}$ & 0 & 45 \\
\hline & \multirow{2}{*}{ D. maschalogena } & $18^{\circ} 40^{\prime} 44^{\prime \prime} \mathrm{N}$ & WPA & 0 & $2.9 \times 10^{5}$ & 0 \\
\hline & & $98^{\circ} 50^{\prime} 25^{\prime \prime} \mathrm{E}$ & V8 juice agar & 0 & $3 \times 10^{5}$ & 2 \\
\hline & \multirow{2}{*}{ B. recurvulum } & $18^{\circ} 40^{\prime} 44^{\prime \prime} \mathrm{N}$ & WPA & 0 & $3.5 \times 10^{4}$ & 11 \\
\hline & & $98^{\circ} 50^{\prime} 25^{\prime \prime} \mathrm{E}$ & V8 juice agar & $5 \times 10^{3}$ & $2.3 \times 10^{4}$ & 14 \\
\hline & \multirow{2}{*}{ T. cymbifolium } & $8^{\circ} 35^{\prime} 19^{\prime \prime} \mathrm{N}$ & WPA & $1.1 \times 10^{4}$ & 0 & 2 \\
\hline & & $98^{\circ} 29^{\prime} 12^{\prime \prime} \mathrm{E}$ & V8 juice agar & $7.5 \times 10^{3}$ & 0 & 0 \\
\hline & \multirow{2}{*}{ M. submacrocarpum } & $8^{\circ} 35^{\prime} 19^{\prime \prime} \mathrm{N}$ & WPA & 0 & $4.9 \times 10^{4}$ & 4 \\
\hline & & $98^{\circ} 29^{\prime} 12^{\prime \prime} \mathrm{E}$ & V8 juice agar & 0 & $6.7 \times 10^{4}$ & 5 \\
\hline & \multirow{2}{*}{ C. purpureus } & $18^{\circ} 40^{\prime} 44^{\prime \prime} \mathrm{N}$ & WPA & 0 & 0 & 0 \\
\hline & & $98^{\circ} 50^{\prime} 25^{\prime \prime} \mathrm{E}$ & V8 juice agar & $5 \times 10^{3}$ & 0 & 0 \\
\hline Total & & & & & & 196 \\
\hline
\end{tabular}

Two commonly used media (V8 juice agar and water proline agar, both supplemented with antibiotics) for isolating actinobacteria and two pre-treatment temperatures (25 and $60{ }^{\circ} \mathrm{C}$ ) were used in this study to isolate actinobacteria. A total of 196 isolates of actinobacteria were obtained from the nine moss species (Table 1 ). A higher number of isolates was obtained from V8 juice agar (108 isolates, 55.1\%) compared to water proline agar (Table 1). Actinobacterial counts inside individual moss plants ranged from 0 to $3 \times 10^{5} \mathrm{CFU} / \mathrm{g}$ (Table 1 ). A slightly lower count was obtained from the rhizosphere soil samples $\left(0-5.9 \times 10^{4} \mathrm{CFU} / \mathrm{g}\right.$, Table 1). The average actinobacterial count was $8.58 \times 10^{4} \mathrm{CFU} / \mathrm{g}$ inside mosses and $1.83 \times 10^{4} \mathrm{CFU} / \mathrm{g}$ in the rhizosphere soil of mosses. The highest number of isolates was obtained from moss species B. buchananii (75 isolates, $38.27 \%$ ), followed by P. microstomum (51 isolates, 26.02\%), Hypnum sp. (29 isolates, $14.8 \%$ ), and B. recurvulum (25 isolates, $12.76 \%$ ) (Table 1). Comparing the efficiency of the two isolation methods, the first method showed abundant growth of fast-growing bacteria that were not actinobacteria. The drying process at $60{ }^{\circ} \mathrm{C}$ in the second method worked well at eliminating fast-growing high-temperaturesensitive bacteria and yielded up to $10^{5} \mathrm{CFU} / \mathrm{g}$ of actinobacteria. Based on their colony 
morphology on Seino's and Waksman's agar slants, these 196 isolates of actinobacteria were grouped and reduced to 89 isolates for the remaining analyses. Each of the 89 isolates had a distinct colony morphology on Seino's and/or Waksman's agar slants.

\subsection{Testing for Plant Growth Promoting Potential}

In this study, we examined the production of three known types of plant-growthpromoting substances by the actinobacteria isolated from mosses and moss-associated soil in Thailand. The three types of substances are indole-3-acetic acid (IAA), siderophores, and tricalcium phosphate solubilizers.

Among the 89 analyzed isolates of actinobacteria, 86 (96.63\%) produced detectable levels of indole-3-Acetic Acid (IAA) in vitro, ranging from $0.04( \pm 0.08)$ to $59.12( \pm 1.99) \mathrm{mg} / \mathrm{L}$ in medium with $2 \mathrm{mg} / \mathrm{mL}$ L-tryptophan supplementation. Most actinobacteria (76.40\%) from mosses produced IAA in the range of $0.01-10 \mathrm{mg} / \mathrm{L}$ (Figure 1). Isolate S3-21 produced the highest IAA at $59.12 \mathrm{mg} / \mathrm{L}$. On average, rhizosphere actinobacteria produced slightly more IAA $(7.37 \pm 1.66 \mathrm{mg} / \mathrm{L})$ than endophytic actinobacteria $(6.51 \pm 1.31 \mathrm{mg} / \mathrm{L})$.

\section{IAA production}

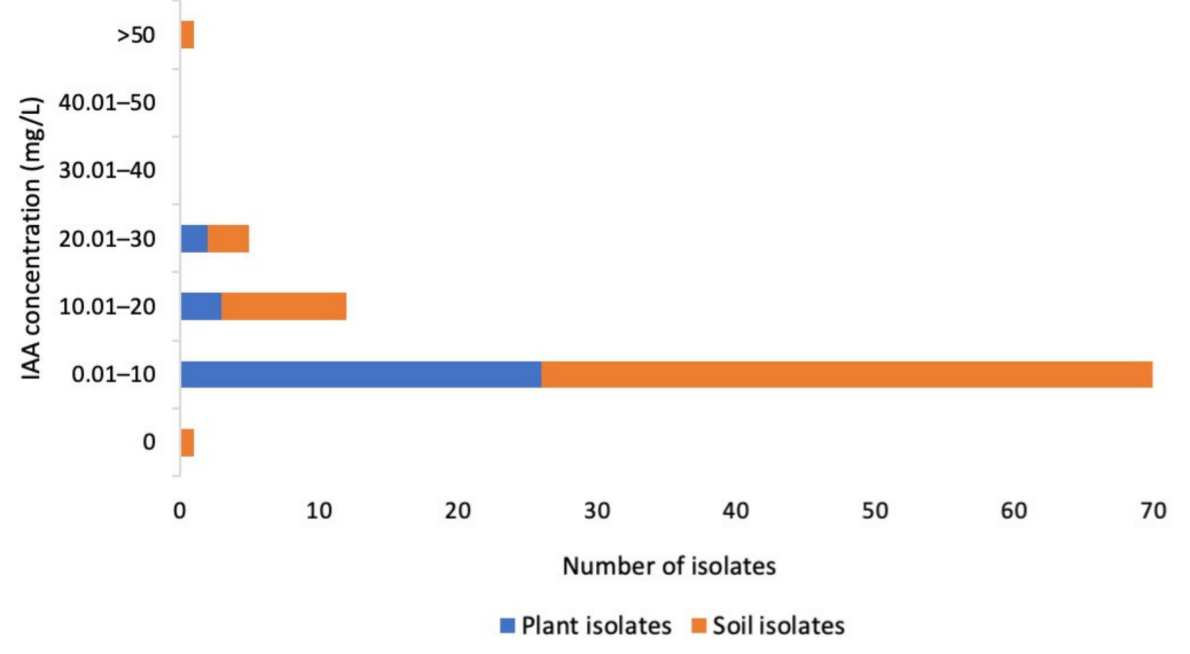

Figure 1. IAA production by actinobacteria from mosses.

A subset of the actinobacteria produced both hydroxamate and catecholate types of siderophores (Figure 2), with 42 isolates producing the hydroxamate type of siderophore $(47.19 \%)$ and 35 isolates producing the catecholate type of siderophore (39.33\%). For hydroxamate siderophore, isolate S32-74 produced the highest amount, at $1949 \mu \mathrm{M}$. For catecholate siderophore, isolate S32-27 produced the highest amount, at $547 \mu \mathrm{M}$ (Figure 2). On average, rhizosphere isolates produced a higher concentration of siderophore than endophytic isolates. The average catecholate siderophore from rhizosphere actinobacteria was $69.36 \pm 13.90 \mu \mathrm{M}$ and from endophytic actinobacteria was $24.64 \pm 6.15 \mu \mathrm{M}$. The average hydroxamate siderophores from rhizosphere actinobacteria and endophytic actinobacteria were $358.43 \pm 73.61$ and $107.33 \pm 31.50 \mu \mathrm{M}$, respectively. Isolate $\mathrm{S} 32-74$ produced the highest hydroxamate siderophore at $1949.17 \pm 80.09 \mu \mathrm{M}$ and isolates S32-27, S32-29, S32-5, and S32-74 produced the highest catecholate siderophore at $489.82 \pm 30.84-547.02 \pm 138.14 \mu \mathrm{M}$. These differences are statistically significant at $p<0.05$ based on one-way ANOVA and Tukey HSD test using the program SPSS.

Tests of phosphate solubilization ability showed that 20 isolates (22.47\%) exhibited clear zones on PVK agar, indicating their ability to solubilize tricalcium phosphate. Overall, actinobacteria isolated from moss-associated soil showed larger clear zones for phosphate solubilization than actinobacteria obtained from inside mosses. Soil isolate S6-28 produced the largest clear zone on PVK agar at $1.75 \pm 0.12 \mathrm{~cm}$ (Table 2). 


\section{Siderophore production}

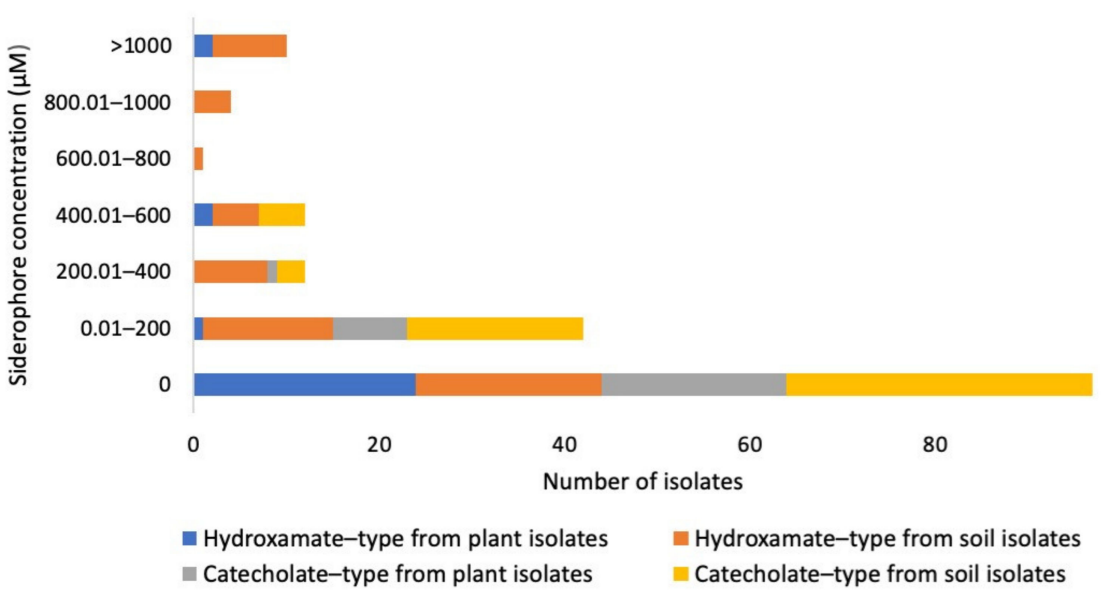

Figure 2. Siderophore production of actinobacteria associated with mosses.

Table 2. Actinobacterial isolates capable of phosphate solubilization. Data for each isolate is based on three repeats $(n=3) .{ }^{\mathrm{a}-\mathrm{d}}$ : isolates with different letters indicate statistically significant differences as determined by SPSS one-way ANOVA and Tukey HSD test $(p<0.05)$.

\begin{tabular}{|c|c|c|c|}
\hline Source & Host Moss Species & Isolate & Clear Zone on PVK Agar $(\mathrm{cm})$ \\
\hline \multirow{5}{*}{ Plant tissue } & B. buchananii & P32-20 & $0.71 \pm 0.11^{\mathrm{ab}}$ \\
\hline & D. maschalogena & P33-17 & $0.96 \pm 0.13^{a b}$ \\
\hline & M. submacrocarpum & P49-10 & $0.71 \pm 0.05^{\mathrm{ab}}$ \\
\hline & M. submacrocarpum & P49-11 & $0.85 \pm 0.08^{a b}$ \\
\hline & M. submacrocarpum & P49-14 & $1.21 \pm 0.74^{b c}$ \\
\hline \multirow{15}{*}{ Soil } & P. microstomum & S3-11 & $0.86 \pm 0.06^{\mathrm{ab}}$ \\
\hline & P. microstomum & S3-16 & $0.95 \pm 0.01^{\mathrm{ab}}$ \\
\hline & P. microstomum & S3-17 & $0.62 \pm 0.03^{\mathrm{ab}}$ \\
\hline & P. microstomum & S3-31 & $0.54 \pm 0.05^{\mathrm{a}}$ \\
\hline & Hypnum sp. & S6-3 & $1.04 \pm 0.04^{\mathrm{ab}}$ \\
\hline & Hyрпит sp. & S6-6 & $0.63 \pm 0.04^{\mathrm{ab}}$ \\
\hline & Hyрпит sp. & S6-14 & $0.51 \pm 0.33^{\mathrm{a}}$ \\
\hline & Hypnum sp. & S6-17 & $0.6 \pm 0^{\mathrm{ab}}$ \\
\hline & Hурпит sp. & S6-28 & $1.75 \pm 0.12^{\mathrm{d}}$ \\
\hline & Hypnum sp. & S6-31 & $1.36 \pm 0.08^{a b}$ \\
\hline & P. maximoviczii & S13-2 & $0.75 \pm 0.14^{\mathrm{ab}}$ \\
\hline & B. buchananii & S32-30 & $0.77 \pm 0.21 \mathrm{ab}$ \\
\hline & B. buchananii & S54-2 & $0.91 \pm 0.02^{\mathrm{ab}}$ \\
\hline & B. buchananii & S54-18 & $0.92 \pm 0.1^{\mathrm{ab}}$ \\
\hline & B. buchananii & S54-19 & $0.87 \pm 0.06^{\mathrm{ab}}$ \\
\hline
\end{tabular}

\subsection{Evaluation of Antimicrobial Activity}

We tested the antimicrobial activities of all 89 actinobacteria isolates from mosses against the seven pathogenic microbial strains. For comparative purposes, we also tested the susceptibilities of these seven pathogens to known antibiotics and/or disinfectants. Our results showed that $S$. aureus ATCC 8923 was susceptible to ampicillin and tetracycline, and the two tested disinfectants $\mathrm{H}_{2} \mathrm{O}_{2}$ and $\mathrm{NaClO}$. However, strain MRSA 43300 was resistant to ampicillin. Strain E. coli 15-318 was resistant to almost all tested drugs and chemicals, except to $10 \% \mathrm{NaClO}$ (10 mm clear zone). Strain P. aeruginosa 13 was susceptible to $10 \%$ $\mathrm{NaClO}(8 \mathrm{~mm})$ and tetracycline $(17 \mathrm{~mm})$ but not susceptible to $4.25 \% \mathrm{H}_{2} \mathrm{O}_{2}$. The $P$. syringae pv. syringae strain 19874 was susceptible to $10 \% \mathrm{NaClO}(12 \mathrm{~mm}), 4.25 \% \mathrm{H}_{2} \mathrm{O}_{2}(15 \mathrm{~mm})$, and tetracycline (33 mm). For the P. destructans strain US15, 4.25\% $\mathrm{H}_{2} \mathrm{O}_{2}$ and $10 \% \mathrm{NaClO}$ 
showed full inhibitions with the zones of inhibition of 15 and $20 \mathrm{~mm}$, respectively (Figure 3). However, because each of the 35 treatments (sterile water + four chemical agents $\times$ seven pathogens) was tested only once, we were unable to determine the statistical significance of the observed differences among treatments.

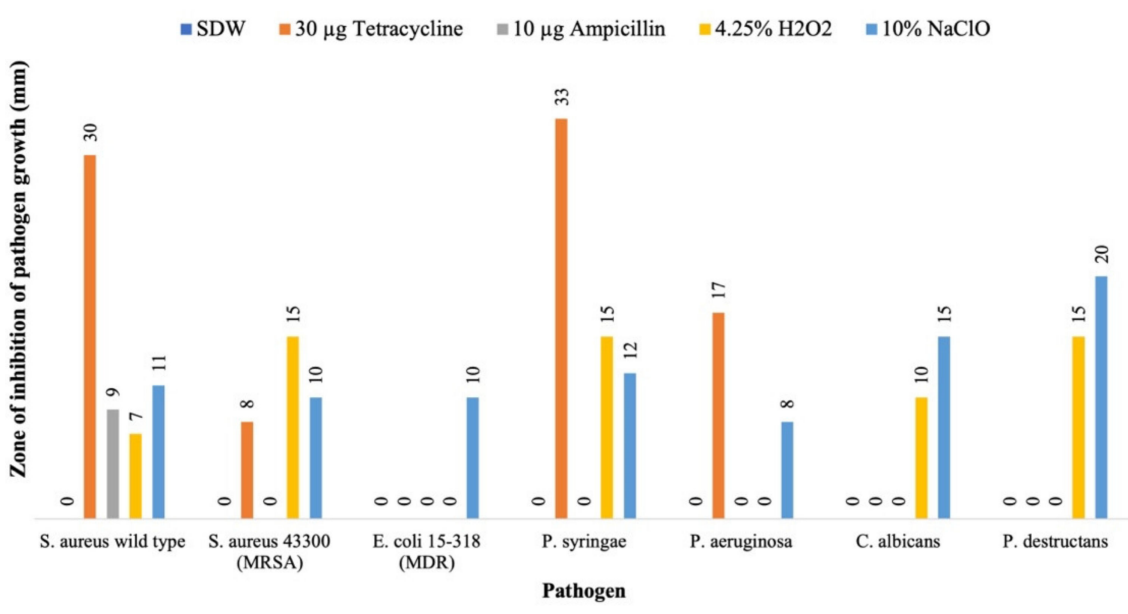

Figure 3. Susceptibilities of the seven microbial pathogens to two known antibiotics and two chemical agents used in this study.

Among the 89 actinobacteria isolates, 16 showed an inhibitory ability against both P. syringae pv. syringae and P. destructans. However, none of the 89 actinobacteria showed inhibition against $P$. aeruginosa. Several isolates showed a broad range of inhibitions, such as isolates S32-63 and S6-14. Isolate S32-63 inhibited the Gram-positive MRSA strain, the Gram-negative P. syringae pv. syringae, and the fungus P. destructans. Isolate S6-14 inhibited strain S. aureus ATCC 8923, the yeast C. albicans, and P. destructans. Several isolates, such as P32-2, P32-11, and P54-15, inhibited only one pathogen each (Figure 4). Interestingly, isolates P54-15, S6-17, and S6-6 completely inhibited the growth of P. destructans on bioassay plates (Figure 5A). Interestingly, 70\% EtOH did not inhibit the growth of $P$. destructans (Figure 5A). The morphology of several isolates showing strong antimicrobial activities against the seven pathogens are displayed in Figure 5B.

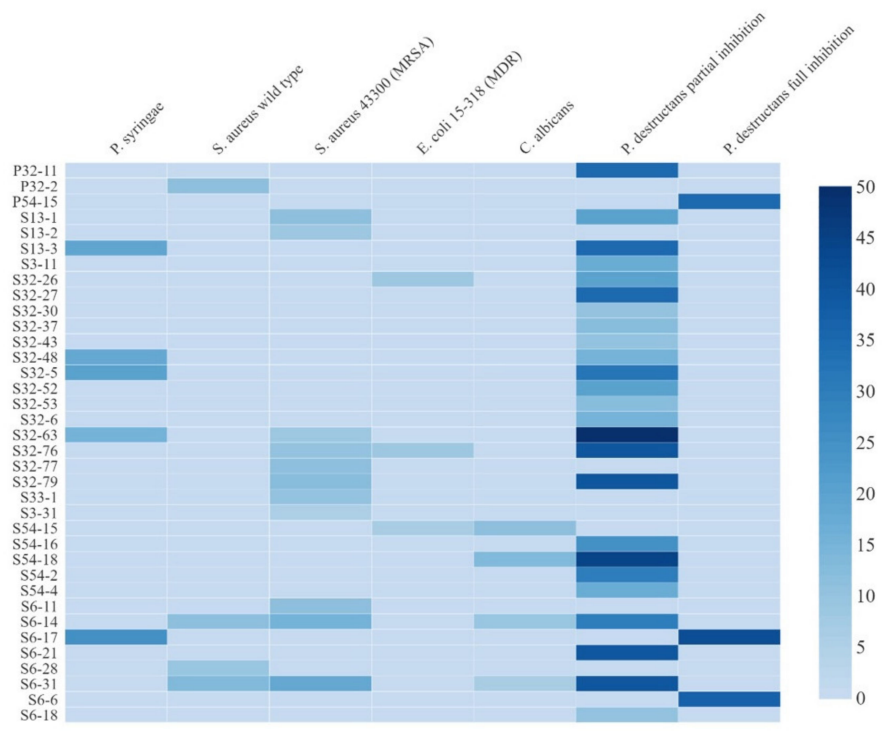

Figure 4. Heat map representing antimicrobial activity of actinobacteria from mosses against two drug-resistant bacteria and two fungal pathogens. The legend on the right size indicates the diameter of the zone of inhibition (in $\mathrm{mm}$ ). 
$\mathbf{A}$
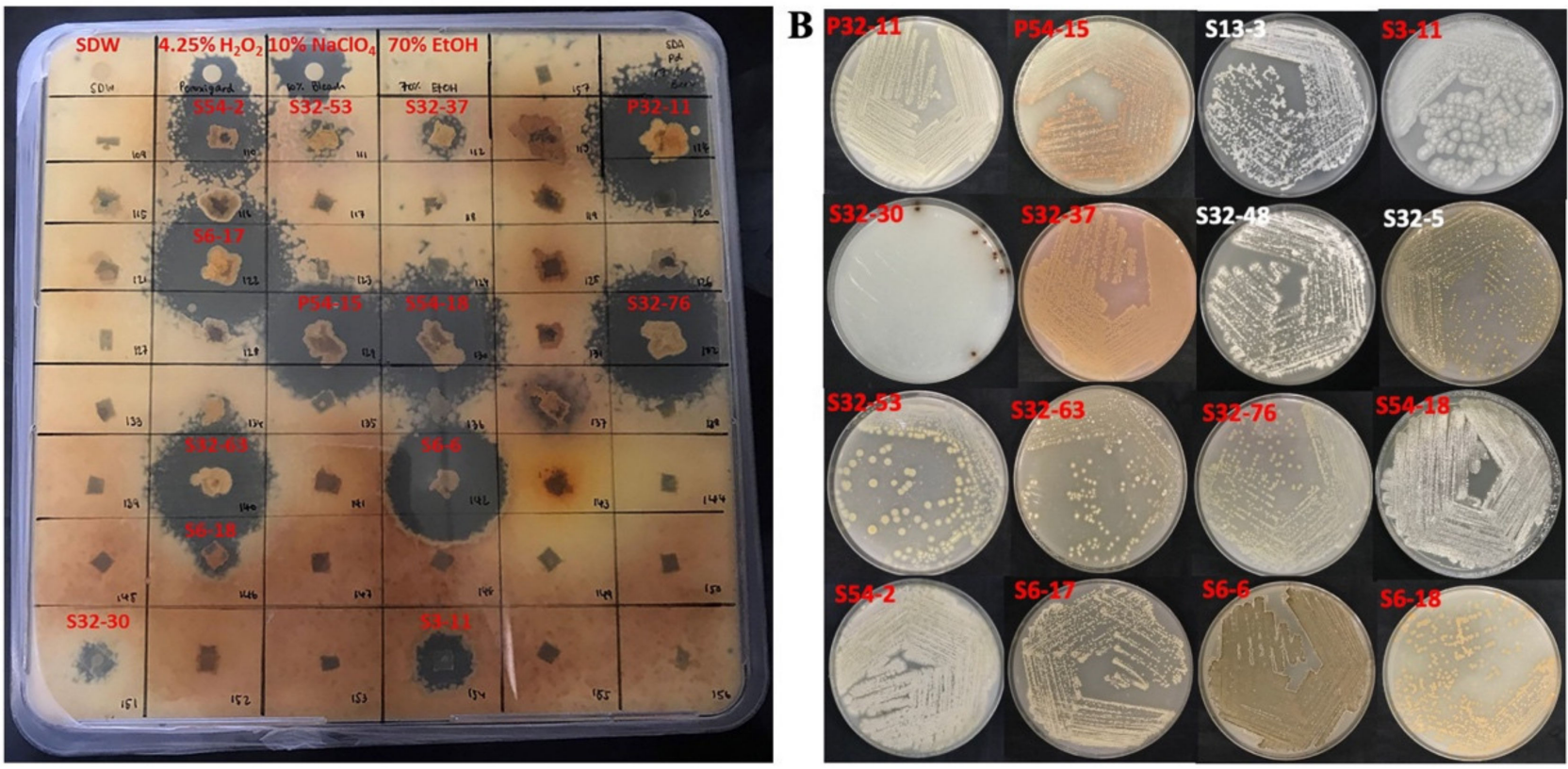

Figure 5. Representative strains that showed inhibition activity against $P$. destructans. (A) AntiP. destructans activity of actinobacteria from mosses. (B) Colony morphological diversity of representative actinobacteria that showed activities against diverse pathogens. Isolates were grown on an ISP3 medium for 2 weeks at $28^{\circ} \mathrm{C}$. Letters in red indicate isolates with anti-P. destructans activity that also showed in (A).

\section{4. $16 S$ rRNA Analysis of Actinobacteria from Mosses}

Among the 89 isolates, 37 strains were selected for $16 \mathrm{~S}$ rRNA sequencing based on their morphological characteristics on ISP2 and ISP3 agar and their antimicrobial activities. These isolates were chosen based on their morphological characteristics on ISP2 and ISP3 agar and their bioactivities. The majority of these 37 actinobacteria belonged to Streptomyces ( 25 isolates, $67.57 \%$ ), which were followed by Micromonospora (4 isolates, $10.81 \%)$, Nocardia (2 isolates, $5.41 \%$ ), Actinoplanes ( 2 isolates, $5.41 \%$ ), Saccharothrix ( 2 isolates, $5.41 \%$ ), Streptosporangium (1 isolate, 2.7\%), and Cryptosporangium (1 isolate, $2.7 \%$ ). All these isolates shared between $98.57 \%$ and $100 \% 16 \mathrm{~S}$ rRNA gene sequence similarity with their nearest known species (Table 3). Phylogenetic analysis confirmed the assignments of all isolates to corresponding genera, in agreement with the BLAST results (Figure 6). Based on the sequence analysis, these 37 isolates likely represent 19 species, with several of them representing potential new species (highlighted in yellow boxes). These seven putative new species were proposed because their 16S rRNA sequences showed greater divergence with their closest known species than the sequence differences between the known sister species within their respective genera (Figure 6). 
Table 3. 16S rRNA sequencing results of actinobacteria from mosses and comparisons with those in the EzBiocloud database.

\begin{tabular}{|c|c|c|c|c|c|}
\hline Genera & Isolate & $\begin{array}{l}\text { DDBJ Accession } \\
\text { Number }\end{array}$ & Top Hit Taxon & $\%$ Similarity & Length (bp) \\
\hline \multirow{26}{*}{ Streptomyces } & P32-2 & LC551864 & Streptomyces althioticus NRRL B-3981 & 100 & 1221 \\
\hline & P32-15 & LC551863 & Streptomyces althioticus NRRL B-3981 & 100 & 1221 \\
\hline & P32-21 & LC551860 & Streptomyces althioticus NRRL B-3981 & 100 & 1221 \\
\hline & P54-7 & LC551871 & Streptomyces althioticus NRRL B-3981 & 100 & 1328 \\
\hline & P54-15 & LC551870 & Streptomyces althioticus NRRL B-3981 & 100 & 1329 \\
\hline & P49-13 & LC551869 & Streptomyces violaceolatus DSM $40438^{\mathrm{T}}$ & 100 & 1344 \\
\hline & P49-18 & LC551868 & $\begin{array}{c}\text { Streptomyces griseoincarnatus LMG } \\
19316^{\mathrm{T}}\end{array}$ & 100 & 1303 \\
\hline & S3-11 & LC551876 & $\begin{array}{c}\text { Streptomyces rhizosphaerihabitans } \\
\text { JR-35 } 35^{\mathrm{T}}\end{array}$ & 99.85 & 1324 \\
\hline & S3-16 & LC551877 & Streptomyces mirabilis NBRC $13450^{\mathrm{T}}$ & 100 & 1338 \\
\hline & S3-17 & LC551878 & Streptomyces aureus NBRC $100912^{\mathrm{T}}$ & 100 & 1355 \\
\hline & S3-26 & LC551872 & Streptomyces wedmorensis NRRL $3426^{\mathrm{T}}$ & 99.55 & 1324 \\
\hline & S3-30 & LC551874 & $\begin{array}{c}\text { Streptomyces camponoticapitis } \\
\text { 2H-TWYE14 }\end{array}$ & 99.62 & 1329 \\
\hline & S6-17 & LC551893 & Streptomyces setonii NRRL ISP-5322 ${ }^{\mathrm{T}}$ & 100 & 1329 \\
\hline & S32-79 & LC551890 & Streptomyces setonii NRRL ISP-5322 ${ }^{\mathrm{T}}$ & 100 & 1335 \\
\hline & S6-31 & LC551895 & $\begin{array}{c}\text { Streptomyces sporoverrucosus NBRC } \\
15458^{\mathrm{T}}\end{array}$ & 100 & 1360 \\
\hline & S32-5 & LC551886 & Streptomyces fulvissimus DSM $40593^{\mathrm{T}}$ & 99.93 & 1359 \\
\hline & S32-27 & LC551891 & Streptomyces fulvissimus DSM $40593^{\mathrm{T}}$ & 99.93 & 1360 \\
\hline & S32-55 & LC551884 & Streptomyces fulvissimus DSM $40593^{\mathrm{T}}$ & 99.93 & 1356 \\
\hline & S32-76 & LC551888 & Streptomyces fulvissimus DSM $40593^{\mathrm{T}}$ & 99.93 & 1353 \\
\hline & S32-10 & LC551885 & $\begin{array}{c}\text { Streptosporangium oxazolinicum } \\
\mathrm{K} 07-0460^{\mathrm{T}}\end{array}$ & 99.25 & 1343 \\
\hline & S32-29 & LC551887 & Streptomyces badius NRRL B-2567 ${ }^{\mathrm{T}}$ & 100 & 1300 \\
\hline & S32-43 & LC551880 & Streptomyces badius NRRL B-2567 & 100 & 1329 \\
\hline & S32-52 & LC551882 & Streptomyces omiyaensis NBRC $13449^{\mathrm{T}}$ & 99.55 & 1343 \\
\hline & S32-65 & LC551889 & Streptomyces globisporus NBRC $12867^{\mathrm{T}}$ & 100 & 1337 \\
\hline & S32-74 & LC551883 & Streptomyces wedmorensis NRRL $3426^{\mathrm{T}}$ & 99.62 & 1330 \\
\hline & S32-77 & LC551881 & Streptomyces dioscori $\mathrm{A} 217^{\mathrm{T}}$ & 99.63 & 1341 \\
\hline \multirow{4}{*}{ Micromonospora } & P32-13 & LC551861 & Micromonospora maritima $\mathrm{D} 10-9-5^{\mathrm{T}}$ & 99.77 & 1324 \\
\hline & P32-19 & LC551862 & Micromonospora marina DSM $45555^{\mathrm{T}}$ & 99.85 & 1331 \\
\hline & P33-11 & LC551867 & $\begin{array}{c}\text { Micromonospora aurantiaca ATCC } \\
27029^{\mathrm{T}}\end{array}$ & 100 & 1296 \\
\hline & S32-33 & LC551892 & $\begin{array}{c}\text { Micromonospora tulbaghiae DSM } \\
45142^{\mathrm{T}}\end{array}$ & 100 & 1326 \\
\hline \multirow{2}{*}{ Actinoplanes } & S3-33 & LC551879 & Actinoplanes lutulentus NEAU-GRX6 ${ }^{\mathrm{T}}$ & 98.57 & 1327 \\
\hline & S6-21 & LC551896 & Actinoplanes consettensis JCM $7624^{\mathrm{T}}$ & 99.93 & 1338 \\
\hline \multirow{2}{*}{ Saccharothrix } & S3-21 & LC551875 & Saccharothrix yanglingensis Hhs. $015^{\mathrm{T}}$ & 98.86 & 1328 \\
\hline & S3-31 & LC551873 & Saccharothrix yanglingensis Hhs. $015^{\mathrm{T}}$ & 98.86 & 1332 \\
\hline \multirow[b]{2}{*}{ Nocardia } & P33-17 & LC551866 & Nocardia fluminea $\mathrm{S} 1^{\mathrm{T}}$ & 99.55 & 1332 \\
\hline & S6-27 & LC551894 & $\begin{array}{l}\text { Nocardia salmonicida subsp. } \\
\text { cummidelens } \mathrm{R} 89^{\mathrm{T}}\end{array}$ & 100 & 1335 \\
\hline Cryptosporangium & P33-8 & LC551865 & $\begin{array}{c}\text { Cryptosporangium minutisporangium } \\
\text { IFO } 15962^{\mathrm{T}}\end{array}$ & 99.92 & 1330 \\
\hline
\end{tabular}




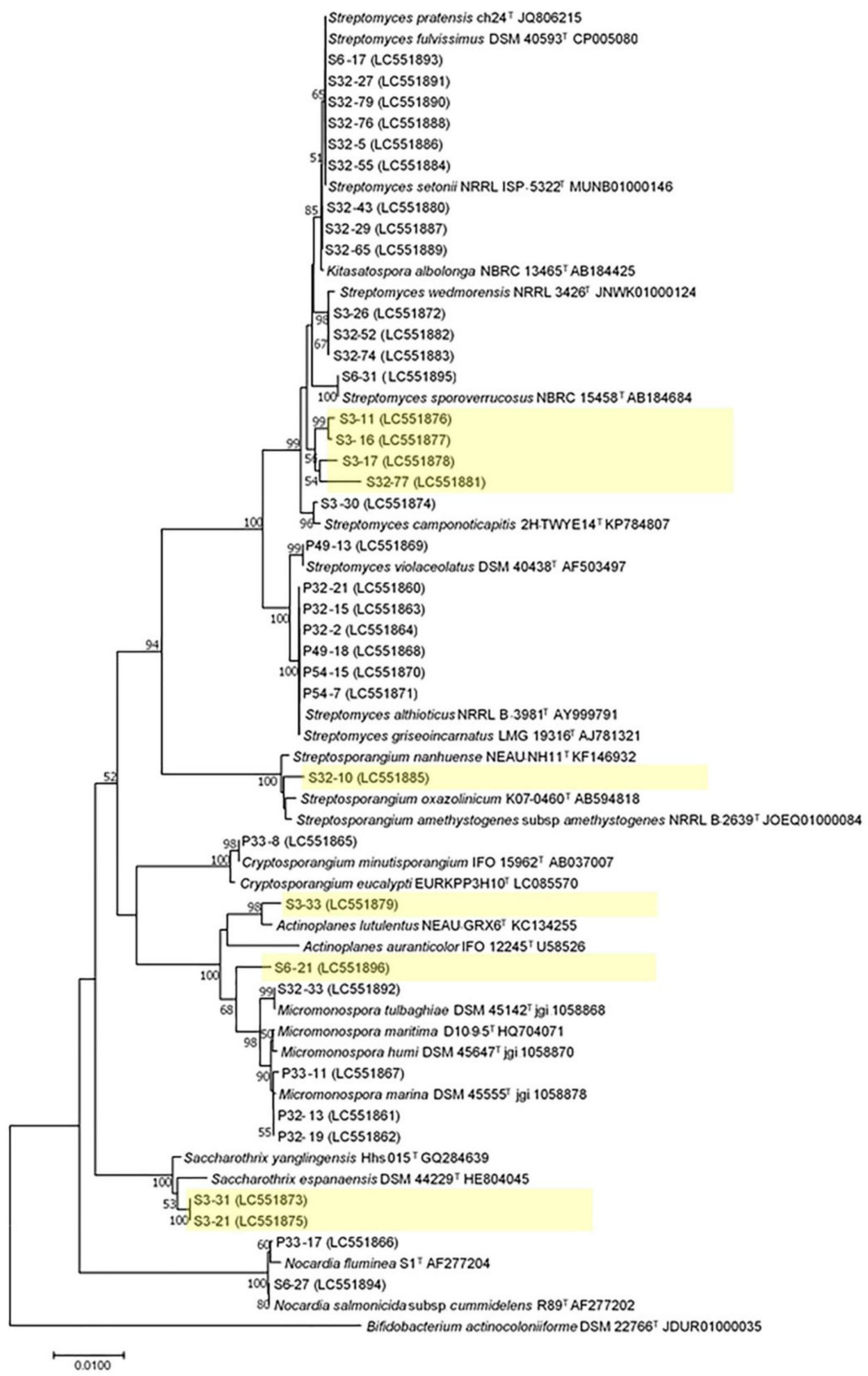

Figure 6. Phylogenetic tree of actinobacteria from mosses. The tree was inferred using the NeighborJoining method [29]. The percentage of replicate trees in which the associated taxa clustered together in the bootstrap test (1000 replicates) are shown next to the branches. The values less than 50 were removed. The evolutionary distances were computed using the Maximum Composite Likelihood method [30]. Evolutionary analyses were conducted in MEGA7. The five highlighted clades in yellow likely belong to seven new species. 


\subsection{GC-MS Results}

Three strains (S. fulvissimus strain S32-76, S. dioscori strain S32-77, and S. setonii strain S32-79) that showed significant antimicrobial activities were chosen for analysis of their metabolite profiles. We compared the results of the GC-MS of each strain with the GCMS profiles of the pure sterilized liquid medium that underwent the same treatments to remove the background noises and to confirm that the compounds were released from actinobacterial cells into the liquid media. Solvent extraction was performed to obtain volatile organic compounds (VOCs) in the liquid media. Then the crude extract was subjected to GC-MS analysis. To obtain a more comprehensive profile of metabolites for each isolate, the crude extract of each isolate was analyzed using two approaches: one without derivatization and the second with derivatization. The process of derivatization allows certain types of metabolites, such as acids and bases, that are otherwise difficult to volatilize by themselves to become volatile with the help of a silylating reagent.

As expected, derivatization had an effect on the detected compounds (Table 4). The major class of compounds before derivatization were alkane (46.75\%), alcohol (12.99\%), and ketone $(3.90 \%)$. After derivatization, the major compounds were alkanes $(15.29 \%)$, carboxylic acid $(10.59 \%)$, sugar $(8.24 \%)$, and alcohol (7.06\%). The details of individual compounds for each strain are presented in Supplementary Table S1. Interestingly, tryptophol was detected from S32-79 before derivatization but not after derivatization. In contrast, maltol was found in the crude extract of strain S32-76 after derivatization but not before. Tris(2,4-di-tert-butylphenyl) phosphate was found with the highest peak area of all isolates before derivatization but disappeared after derivatization.

Table 4. Major classes of compounds detected by GC-MS before and after derivatization.

\begin{tabular}{ccc}
\hline Condition & Compound Nature & $\begin{array}{c}\text { Estimated Compound } \\
\text { Content (\%) }\end{array}$ \\
\hline & Alkane & 46.75 \\
Alcohol & 12.99 \\
Ketone & 3.90 \\
Carboxylic acid & 2.60 \\
& Flavonoid & 2.60 \\
& Amide & 2.60 \\
Alkaloid derivative & Ether & 2.60 \\
& Imide & 2.60 \\
& Ester & 1.30 \\
& Lactone & 1.30 \\
& Others & 1.30 \\
& Alkanes & 19.48 \\
\hline Post-derivatization & Carboxylic acid & 15.29 \\
& Sugar & 10.59 \\
& Alcohol & 8.24 \\
& Sugar alcohol & 7.06 \\
& Fatty acid & 5.88 \\
& Ether & 4.71 \\
& Ester & 3.53 \\
& Amide & 2.35 \\
& Imide & 2.35 \\
& Terpene & 2.35 \\
& Others & 2.35 \\
& & 30.59 \\
\hline
\end{tabular}

For each of the three isolates, the most prominent peaks between pre- and postderivatization were different. Specifically, prominent peaks of S32-76 before derivatization were dihydroergotamine and after derivatization was galactose oxime, with peak areas $0.83 \%$ and $2.07 \%$. They exhibited retention times corresponding to 27.094 and 21.959, respectively. Prominent peaks of S32-77 before and after derivatization were Tris(2,4-di-tert- 
butylphenyl) phosphate and pentadecanoic acid, with peak areas $18.13 \%$ and $0.91 \%$ and retention times of 50.947 and 22.19, respectively. Prominent peaks of strain S32-79 before and after derivatization were Tris(2,4-di-tert-butylphenyl) phosphate and hymexazole, tertbutyldimethylsilyl ether, with peak areas $10.59 \%$ and $1.21 \%$ and retention times of 50.979 and 11.62, respectively. However, it should be noted that peak areas cannot be used to directly calculate the amount of individual compounds. This is because the peak area is not only influenced by the amount of each compound in the extract but also by the properties of the compounds, especially their volatility and susceptibility to ionization. In addition, we observed some prominent unknown peaks that did not match any known compound in the database. For example, in strain S32-79, there are several unknown compounds, such as ones at retention times 21.006 and 22.791. Derivatization increased the number of unidentified compounds; for example, in S32-79, GC-MS detected 22 unidentified compounds in pre-derivatization and 128 unidentified compounds in post-derivatization.

The GC-MS revealed that the three isolates were able to produce diverse putative bioactive compounds in vitro (Supplementary Figure S1). Some VOCs were found in common among the three isolates, including hexadecane and 3-methyl-octadecane. Among the three isolates, the highest number of VOCs before derivatization was detected in strain S32-76 with 36 VOCs. After derivatization, strain S32-79 showed the highest number of VOCs with 33 VOCs. The details of the GC-MS profile for each of the three isolates before and after derivatization are shown in Supplementary Table S1. References [31-78] are included in Supplementary Table S1 and they describe the features of the compounds we identified through GC-MS.

Before derivatization, VOCs commonly shared between S. fulvissimus S32-76 and S. dioscori S32-77 were dihydroergotamine, octacosanol, pinostrobin, octadecylcyclohexane, 10,11-dihydrofarnesol, 5-methylheneicosane, and 1-iodo-octacosane. The most commonly shared VOCs between S. dioscori S32-77 and S. setonii S32-79 were 3-methyl-octadecane and hexadecane. Furthermore, the commonly shared VOCs between S. fulvissimus S32-76 and S. setonii S32-79 were phenylethyl alcohol, 1,1'-(1,3-phenylene) bisethenone, 3,6-diisopropyl2,5-dioxomorpholine, and pentacosane. However, a large number of VOCs were not shared among the three strains, including (i) cyclotetradecane, 3-methyl-heptadecane, and humulenol-II (found only in S32-76); (ii) 1-octadecanol methyl ether, crotonic acid menthyl ester, 2-dodecen-1-yl(-)succinic anhydride (found only in S32-77); and maltol, succinimide, and tryptophol (found only in S32-79).

After derivatization, the VOCs shared among all three isolates were p-benzoquinone, myristic acid, 5-methyl-heneicosane, pyrrole-2-carboxylic acid, erythritol, and 4-hydroxybenzyl alcohol. The VOCs found in both S. fulvissimus S32-76 and S. dioscori S32-77 include 1phenyl-1,2-ethanediol, melamine $\mathrm{N}$-(trimethylsilyl), hexadecane, and $\beta$-gentiobiose. The VOCs shared between $S$. dioscori S32-77 and S. setonii S32-79 were pyrrole-2-carboxylic acid, arabinofuranose; pentadecanoic acid, and 1-monopalmitin. The VOCs shared between S. fulvissimus S32-76 and S. setonii S32-79 were phenylethyl alcohol, p-toluic acid, anthranilic acid, (1E)-d-Glucose-2,3,4,5,6-pentakis-O-(trimethylsilyl)-o-methyloxyme, glucose, and tetracontane. Some VOCs after derivatization were found only in one of the three strains, e.g., urea, xylitol, and tryptophol in strain S32-76; benzenebutanoic acid, crotonic acidmenthyl ester in strain S32-77; and pyruvic acid and maltol in strain S32-79.

GC-MS detected several bioactive compounds with reported bioactivity in promoting plant growth, including 2,3-dihydroxybenzoic acid, a catecholate siderophore with antimicrobial activity, and L-tryptophan, a substrate for IAA production, in the crude extract of S32-77. The ethyl acetate extracts of strains S32-76, S32-77, and S32-79 were also tested against MRSA. These extracts inhibited the growth of MRSA with the sizes of clear zones ranging from 10 to $14 \mathrm{~mm}$ (Table 5). These results confirm the bioactivity of actinobacterial extract injected into GC-MS. The activity of MRSA inhibition and colony of three potential isolates were represented in Figure 7. 
Table 5. The anti-MRSA activity measured after incubation for 3 days at $28^{\circ} \mathrm{C}$ on nutrient agar. The zone of inhibition indicated activity against the growth of MRSA. Each disk contained $1.6 \mathrm{mg}$ of crude extract.

\begin{tabular}{cc}
\hline Isolates & $\begin{array}{c}\text { Activity of Crude Extract against MRSA } \\
(\mathbf{m m}, \pm \text { Standard Error) }\end{array}$ \\
\hline Absolute Ethanol (negative control) & $0( \pm 0)$ \\
Tetracycline (positive control) & $8( \pm 0.3)$ \\
S32-76 & $10( \pm 0.3)$ \\
S32-77 & $13( \pm 0.4)$ \\
S32-79 & $14( \pm 0.4)$ \\
\hline
\end{tabular}

A
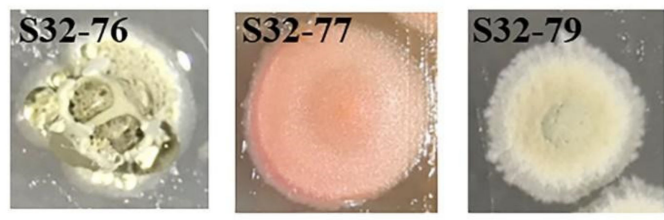

B

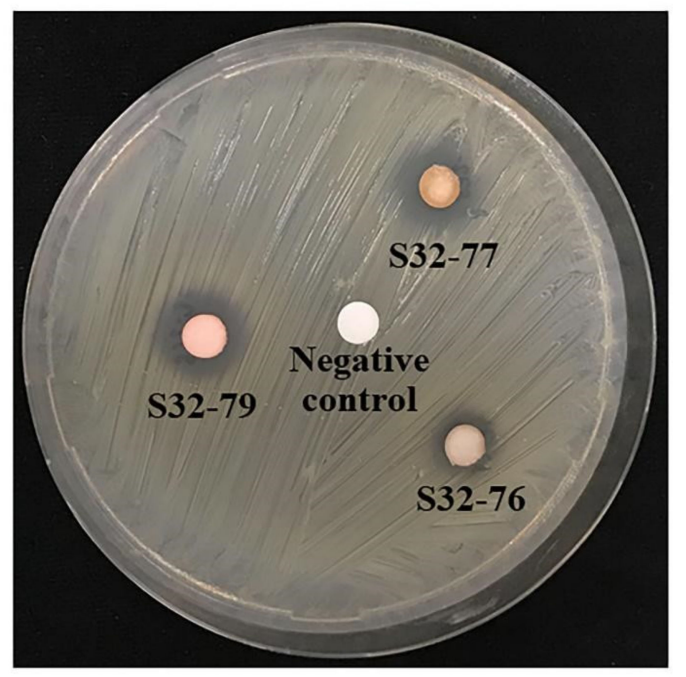

Figure 7. Colonies of three selected Streptomyces isolates (strains S32-76, S32-77, and S32-79) (A); and their activities against MRSA in their ethyl acetate extracts of cell culture supernatant (B). In (A), colony morphology was observed on an ISP3 medium after seven days of incubation at $28{ }^{\circ} \mathrm{C}$ under stereomicroscope. In (B), three paper disks (6 mm in diameter) loaded with $40 \mu \mathrm{L}$ of crude extracts were plated on nutrient agar overlayed by MRSA. The center was a negative control disk loaded with $40 \mu \mathrm{L}$ of absolute ethanol. All discs were completely dried before placing on the plate.

\section{Discussion}

In this study, we surveyed the diversity of actinobacteria from representative mosses in northern Thailand and investigated their potential bioactive repertoires. Our surveys revealed that actinobacteria were common both inside mosses (with a mean of $8.58 \times 10^{4} \mathrm{CFU} / \mathrm{g}$ ) and in the rhizosphere soil of mosses (mean of $1.83 \times 10^{4} \mathrm{CFU} / \mathrm{g}$ ). An early study from Japan [79] reported the mean density of actinobacteria in the rhizosphere of diverse vascular plants was around $10^{7} \mathrm{CFU} \mathrm{g}^{-1}$ (dried sample) and a range of $10^{3}-10^{5} \mathrm{CFU} \mathrm{g}^{-1}$ (dried sample) from the tissues of plants. Our estimated low density of actinobacteria in rhizosphere soil of mosses might be due to the differences in soil characteristics and geographic locations. For example, the optimum soil pH of bryophytes (including mosses) is slightly acidic, ranges from 4.5 to 7.2 [80], and is not conducive to actinobacteria growth. Indeed, previous studies showed that the relative abundance of actinobacteria decreased with decreasing $\mathrm{pH}$ [81]. Similarly, in waterlogged, anaerobic soils and acidic soils, the numbers of actinobacteria are typically low $\left(10^{2}-10^{3} \mathrm{~g}^{-1}\right.$ dry weight soil), lower than what we found here [82]. 
The preheating step for soil and moss samples eliminated fast-growing microbes and enhanced the recovery of the slow-growing actinobacteria from mosses up to $10^{5} \mathrm{CFU} / \mathrm{g}$. Heat pre-treatment has been frequently used for removing non-actinobacteria microbes from soil samples to help obtain a higher amount of rare actinobacteria [83]. V8 juice agar, which has been widely used for fungal isolation, was also conducive for isolating actinobacteria when supplemented with Benomyl, a fungicide. Water proline agar (WPA) is generally preferred by Streptomyces [84]. However, we found that WPA resulted in a similar growth density of actinobacteria as V8 juice agar. Humic acid vitamin agar (HVA), tap water yeast extract agar (TWYA), and starch casein agar (SCA) are the other frequently used isolation media for endophytic actinobacteria [85]. Additional attempts using these three types of media (HVA, TWYA, and SCA) may allow us to obtain novel actinobacteria species and strains. For plant samples, surface sterilization of plant parts before plating on isolation media are often sufficient to remove epiphytic microbes and enhance the efficiency for isolating actinobacteria from the plant endosphere $[85,86]$. Overall, our results showed that the protocols used in our study were effective at isolating actinobacteria from mosses and moss-associated soils.

Actinobacteria are known to produce plant hormones, such as auxins, gibberellin, and cytokinin. In this study, Saccharothrix yanglingensis Hhs.015 ${ }^{\mathrm{T}} \mathrm{S} 3-21$ produced the highest IAA at $59.12 \pm 1.99 \mathrm{mg} / \mathrm{L}$ on medium supplemented with $2 \mathrm{mg} / \mathrm{mL}$ L-tryptophan. Overall, IAA production of actinobacteria from mosses was similar or lower than those of actinobacteria from other plants. For example, Streptomyces sp. strain DBT204, an endophytic actinobacterium of tomato Solanum lycopersicum produced $46.3 \mathrm{mg} / \mathrm{L}$ IAA under conditions identical to what we used here, lower than our highest IAA-producing strain S3-21 but higher than most of our other 88 strains [87]. Thus far, the highest IAAproducing actinobacteria, at $222.75 \mathrm{mg} / \mathrm{L}$, was isolated from mandarin orange [88].

Siderophores are low-molecular-weight chelating agents (200-2000 Da) that have various chemical structures belonging to at least 500 different compounds [89]. Siderophores can also act as signaling molecules. In mammalian hosts, siderophores are required for full virulence of pathogens during infection [90,91]. As iron is a macronutrient in plants, the production of siderophores by actinobacteria can increase iron acquisition and uptake from the environment, thus enhancing the availability of iron to plant roots in the form of bacterial siderophore-iron complex, or phytosiderophore-iron [1]. The production of siderophore by plant-beneficial actinobacteria in biocontrol applications can limit the access of iron to phytopathogenic bacteria. Indeed, $86.8 \%$ of actinobacteria isolated from tomato plants could produce siderophores, and they have been shown to contribute to tomato growth. Actinomycetes isolated from eaglewood could produce hydroxamate-type siderophore ranging between $3.21 \pm 0.12$ and $39.30 \pm 0.40 \mu \mathrm{g} / \mathrm{mL}$ and catechols-type at $4.12 \pm 0.90 \mu \mathrm{g} / \mathrm{mL}$ [92]. Prior to our study, the highest hydroxamate siderophore production by Actinobacteria from bryophytes was at $992.50 \pm 50.76 \mathrm{mM}(1.51 \mu \mathrm{g} / \mathrm{mL})$, and the highest catecholate siderophore was at $484.47 \pm 27.91 \mathrm{mM}(3.14 \mu \mathrm{g} / \mathrm{mL})$ [12]. In our study, high percentages of actinobacteria from mosses produced hydroxamate and catecholate siderophores. The highest siderophore productions of our actinobacteria from mosses were $1949.17 \pm 80.09(2.97 \mu \mathrm{g} / \mathrm{mL})$ and $547.02 \pm 138.14 \mu \mathrm{M}(3.55 \mu \mathrm{g} / \mathrm{mL})$ for hydroxamate and catecholate siderophores, respectively, higher than those reported previously. At present, the reasons for the differences in the amount of IAA and siderophore productions among actinobacteria from mosses and between mosses and other plants are not known.

Phosphate is an essential nutrient in plant growth and development. Phosphorussolubilizing microorganisms (PSMs) can release organic acid or $\mathrm{H}^{+}$ions to help plants access the reservoir of non-labile phosphorus and release it from its recalcitrant forms [93]. Previous studies have shown that some actinobacteria can solubilize phosphate through different mechanisms. For example, using a synthetic minimal medium with rock phosphate as a sole carbon source, several actinobacteria in genera Streptomyces and Micromonospora converted rock phosphate into soluble phosphate by the production of siderophore, not organic acids [94]. The proportion of actinobacteria that could solubilize phosphate in our 
sample was similar to that reported earlier [95] that showed $25.9 \%$ of actinobacteria from Rhynchotoechum ellipticum endospheric tissues could solubilize phosphate under in vitro conditions determined by a clear zone on PVK agar. Actinobacteria in the genus Streptomyces and Acinetobacter [96] are known for their ability to solubilize phosphate. In this study, we discovered that actinobacteria belonging to three genera Nocardia, Streptomyces, and Saccharothrix were capable of solubilizing phosphate on PVK agar. Previous studies have shown that inoculating plants with plant-growth-promoting rhizobacteria (PGPR) or treating plants with microbe-to-plant signal compounds could stimulate plant growth and improve crop tolerance against abiotic stresses [93]. In addition, our previous study showed that inoculation of plant-growth-promoting actinobacteria to moss gametophytes increased fresh weight, dry weight, carotenoid content, and capsule production in mosses, and helped mosses acclimatize to outdoor field soil conditions [12]. Indeed, actinobacteria, as well as microbes in other genera, such as Bacillus, Pseudomonas, and Lactobacillus, have been used commercially to enhance plant productions [93]. We believe that the actinobacteria obtained here could also enhance the growth and reproduction of mosses. However, further experimental investigations are needed to confirm their plant growth-enhancing roles.

The bioassay of actinobacteria from mosses against $P$. aeruginosa 13 and $P$. syringae pv. syringae 19874, MRSA 43300, S. aureus ATCC 8923, E. coli 15-318, C. albicans 012 and $P$. destructans strain US15 showed different results. Five and thirteen actinobacteria inhibited $P$. syringae pv. syringae and P. destructans, respectively. Isolate S6-17 was closely related to Streptomyces setonii and S32-5 was closely related to Streptomyces fulvissimus, both inhibited P. syringae pv. syringae. There have been successful examples of using actinomycetes or their active compounds to treat $P$. syringae infections. For example, Kasugamycin is an aminoglycoside antibiotic isolated from Streptomyces kasugaensis that is approved for controlling P. syringae pv. actinidiae, the bacteria causing kiwifruit canker [97]. Similarly, Actinomycetes from hypersaline soil in Turkey inhibited P. syringae pv. tomato in vitro [98] and Actinomycetes isolated from Antarctica showed inhibition on phytopathogenic bacteria, $P$. syringae pv. syringae and $P$. syringae pv. tabaci [99].

Interestingly, Streptomyces from this study, could inhibit $P$. destructans growth effectively. Isolate P54-15 (closely related to Streptomyces althioticus) and S6-17 (closely related to Streptomyces setonii) showed full inhibition against $P$. destructans. S3-11 (closely related to Streptomyces rhizosphaerihabitans) and S32-76 (closely related to Streptomyces fulvissimus) showed partial inhibition against $P$. destructans. The results here are consistent with an earlier study [100], showing that the most effective bacterial antagonists against $P$. destructans were from the genera Bacillus, Pantoea, Streptomyces, Pseudomonas, Rahnella, Arthrobacter, and Sphingobium. The volatile compounds produced by antagonists, such as 2-methyl-1propanol, 2-methyl-1-butanol, propanoic acid, and 1-pentanol, could inhibit the growth of P. destructans [100]. The mechanism for the observed antifungal antagonists was likely due to the secretion of antifungal compounds and/or hydrolytic enzymes, such as chitinase, $\beta, 3$ glucanase, chitosanase, and proteases [84].

In this study, we found that isolates from the rhizosphere soil of mosses showed a greater ability to inhibit the pathogens than those of endophytic isolates from mosses. Indeed, populations of actinobacteria inside and outside mosses were found to have distinct characteristics in both their species distributions and putative functions. Based on morphological characteristics and molecular identifications, out of the seven genera, two (Cryptosporangium and Nocardia) were only isolated from inside mosses, not from their rhizosphere soil. In contrast, three genera (Saccharothrix, Actinoplanes, and Streptosporangium) were only isolated from soil samples but not inside mosses. Overall, in our samples, the species richness in the rhizosphere soil was higher than the moss's interior. Our results also suggest several potentially new species (shown in yellow highlighted in Figure 6) in the genera Actinoplanes, Saccharothrix, and Streptomyces. Indeed, a novel species of actinobacterium Streptomyces bryophytorum was recently isolated from an unidentified moss [101]. Among the seven genera, Cryptosporangium spp. has also been isolated from plant litter [102,103] or as endophytes of plants [104]. Due to the close phylogenetic relationships among known 
species and between many of our samples and those known species, the final taxonomic placements of most of our isolates, especially the yellow-highlighted ones, such as S3-21 and S3-31, in Figure 6, await further investigation using either multilocus sequence typing or whole-genome sequencing. Soil is a dominant niche of actinobacteria, especially for genera Sacchrothrix and Actinoplanes [105-110]. A previous metagenomic analysis of endophytic bacteria of the xerophilous moss Grimmia montana revealed the bacterial community inside this moss was composed of Proteobacteria, Firmicutes, Actinobacteria, and Cytophaga/Flexibacter/Bacteroids [13]. Overall, metagenomics-based studies of endophytic actinobacteria revealed that Streptomyces sp. was the most abundant genus [1,3], similar to what we found in this study.

Previous studies have shown that polyketide (PK) and non-ribosomal peptide (NRP) natural products from Streptomyces contain notable antimicrobial and anticancer activities (e.g., [111]). Type III PKSs were originally believed to be plant-specific, but it was later found in S. griseus in 1999 [112]. With the use of genetic screening, traditional Chinese herbs were found to contain endophytes capable of synthesizing bioactive compounds through the non-ribosomal peptide synthetase (NRPS) and polyketide synthase (PKS) genes [113]. In addition to their antimicrobial activities, a variety of siderophores are encoded from NRPS genes [112,113]. Whole-genome sequencing of the isolates with strong antimicrobial activities will help reveal whether the strains isolated in our study have the potential for producing PK and NRP natural products. In addition, the whole-genome sequences combined with LC-MS and Global Natural Products (GNPS) Social Molecular Networking analyses could help reveal the interconnections among metabolites in these actinobacteria.

A previous study [113] analyzed the mechanism of Streptomyces strains that could inhibit E. coli BW25113, Pseudomonas aeruginosa PA01, and Bacillus subtilis 168 through a combination of UHPLC-HRMS experiments and genome analysis. They identified that the most common gene clusters for secondary metabolites were those for producing the terpenes. In addition, the production of terpenes by endophytic Streptomyces was correlated to the quantities of terpenes within those bryophytes. Terpenoids made by bryophytes are responsible for diverse biological and ecological processes, particularly as defenses against biotic and abiotic stresses [114].

Volatile organic compounds produced by microbes have attracted significant attention for understanding the interactions among organisms, including between plants and microbes. In our analyses of the three strains, many VOCs were identified. Among these, dihydroergotamine and Tris(2,4-di-tert-butylphenyl) phosphate have been reported to be produced by actinobacterium Exiguobacterium mexicanum MSSRFS9 [43] that had potent antimicrobial and anti-inflammatory activities, respectively [51,115]. Myristic acid, decane, tetradecane, hexadecane, nonadecane, and heneicosane detected here have shown antimicrobial effects, as demonstrated in previous studies [36,68,69]. Interestingly, many of the VOCs identified here have been detected in plant extracts. For example, extracts of the milky mangrove Excoecaria agallocha leaves contained $2.65 \%$ of pentadecanoic acid and showed antimicrobial activity against E. coli, S. aureus, P. aeruginosa, and C. albicans [97]. Decane was reported in Artimisia plants, which is well-known for its anti-malaria activity [31]. The essential oil of Artimisia aucheri that can inhibit E. coli, S. aureus, and Listeria monocytogenes, contained decane and other compounds, such as $\rho$-cymene, 1,8 -cineole, and linalool [31]. Endophytic actinobacteria of tropical plants commonly contain NRPS genes and genes of PKS I and PKS II [116]. It is highly likely that the actinobacteria from these plants contributed to the productions of the detected antimicrobial VOCs.

Our study detected significant differences in VOC compositions between the prederivatization and post-derivatization samples for each of the three strains. The detected VOC differences were due to differences in how VOCs were generated and prepared for GC-MS analyses by the two sample treatment methods. Specifically, the VOCs detected from the samples before derivatization were those emitted directly by the microbial cultures, while VOCs detected from samples after derivatization include both the originally emitted VOCs and those that were originally not volatile but became volatile after derivatization. 
In addition, several novel VOCs were detected. Further investigations of these VOCs may allow us to identify their unique structural and functional properties.

Until recently, few studies have focused on volatile organic compounds from actinobacteria. However, a recent study [117] revealed a new role for actinobacterial volatile compounds in modulating nutrient availability and microbial community behavior. The volatile compounds, trimethylamine (TMA), from Streptomyces venezuelae influenced a new form of Streptomyces growth called "exploration". TMA can also alter the environment around the exploring area by altering iron availability and enhancing siderophore production and uptake. In our GC-MS analyses of VOCs from the three strains, TMA was not detected. However, this was likely due to the liquid culture medium we used in our study instead of solid agar media needed to show the exploration phenotype. Changing the culture condition could lead to the detection of TMA, other VOCs, and other metabolites.

\section{Materials and Methods}

\subsection{Sample Collection}

Moss samples were collected from Doi Inthanon National Park, Chiang Mai, Thailand, using sterile forceps and stored in zip-lock bags at $4{ }^{\circ} \mathrm{C}$. Mosses were identified to genus and species based on their morphology and microscopical anatomy using the related keys and checklists described in previous publications [118-127].

\subsection{Isolation of Actinobacteria from Mosses and Moss-Associated Soils}

Two common methods for isolating actinobacteria from natural environments were used in this study to isolate actinobacteria from mosses and moss-associated soils from Thailand. These two methods are described below.

In Method 1, the mosses were first transferred to a sterile $50 \mathrm{~mL}$ centrifuge tube and shaken to separate the mosses from the soil attached to them. Soil samples were placed in the silica gel chamber for 3 days and were then used to prepare a serial dilution with Winogradsky's salts solution ( $3.8 \mathrm{~g} \mathrm{~K}_{2} \mathrm{HPO}_{4}, 1.2 \mathrm{~g} \mathrm{KH}_{2} \mathrm{PO}_{4}, 5.1 \mathrm{~g} \mathrm{MgSO}_{4} \cdot 7 \mathrm{H}_{2} \mathrm{O}, 2.5 \mathrm{~g} \mathrm{NaCl}$, $0.05 \mathrm{~g} \mathrm{Fe}_{2}\left(\mathrm{SO}_{4}\right)_{3}$, and $0.05 \mathrm{~g} \mathrm{MnSO}_{4} \cdot 5 \mathrm{H}_{2} \mathrm{O}$ in $1000 \mathrm{~mL}$ deionized water) [128] before plating. The moss samples were rinsed twice with $30 \mathrm{~mL}$ sterile distilled water. This was then followed by submerging the moss samples in $1 \% \mathrm{NaClO}$ for $1 \mathrm{~min}, 70 \% \mathrm{EtOH}$ for $1 \mathrm{~min}$, and sterile distilled water for $1 \mathrm{~min} 2$ times. Moss samples were then placed onto sterile filter paper in a silica gel chamber for 3 days before they were weighed and grounded using a sterile mortar. Winogradsky's salts solution was used to make a serial dilution. Appropriate dilutions of moss samples in Winogradsky's salts solution were inoculated in water proline agar (1\% L-proline) and V8 juice agar $\left(20 \mathrm{~mL}\right.$ of V8 Juice, $3 \mathrm{~g}$ of $\mathrm{CaCO}_{3}$, and $15 \mathrm{~g}$ of agar in $1000 \mathrm{~mL}$ tap water, $\mathrm{pH}$ 7.2) using the pour plate technique. Both media were supplemented with $25 \mu \mathrm{g} / \mathrm{mL}$ nalidixic acid and $25 \mu \mathrm{g} / \mathrm{mL}$ benomyl. Plates from the soil samples and from crushed moss tissues were incubated at $25^{\circ} \mathrm{C}$ for 1 week and 4 weeks, respectively. The final rinse water from the surface sterilization step of each moss sample was plated in water proline agar to confirm the effectiveness of the surface sterilization method.

In Method 2, the moss samples were transferred to a sterile $50 \mathrm{~mL}$ centrifuge tube and shaken to separate the soil attached to them. The soil samples were dried in a $60^{\circ} \mathrm{C}$ oven for $2 \mathrm{~h}$, which were then used to prepare a serial dilution with Winogradsky's salts solution before plating. For moss samples, they were surface sterilized by submerging in $1 \% \mathrm{NaClO}$ for $1 \mathrm{~min}, 70 \% \mathrm{EtOH}$ for $1 \mathrm{~min}$, and sterile distilled water for $1 \mathrm{~min}$. This step was repeated twice. The surface-sterilized samples were then dried in a $60^{\circ} \mathrm{C}$ oven for $2 \mathrm{~h}$ before they were weighed and ground using a sterile mortar. The samples were serially diluted in Winogradsky's salts solution and plated in the same media and incubation condition as described in Method 1.

Presumptive actinobacterial colonies that appeared on isolation plates were picked and purified on Seino's agar. Seino's and Waksman agar slants [84] were used to examine the morphology of putative actinobacteria based on their aerial mycelial and substrate 
mycelial colors. The ISCC-NBS color chart [129] was used to determine the color of mycelia. Actinobacterial isolates were assigned a code with the letter $\mathrm{S}$ or P; $\mathrm{S}$ indicated the isolates obtained from soil samples, and P indicated the isolates obtained from plant tissue samples.

\subsection{In Vitro Quantifications of Metabolites with Plant Growth Promoting Potentials}

The potential abilities of actinobacteria to produce the following three types of known plant-growth-promoting substances were investigated in this study: indole-3-acetic acid (IAA), siderophores, and tricalcium phosphate solubilizers.

IAA production was determined following the method described previously [130]. In brief, actinobacteria were grown in an ISP2 liquid medium supplemented with $2 \mathrm{mg} / \mathrm{mL}$ L-tryptophan for 7 days at $28^{\circ} \mathrm{C}$ (dark condition). After 7 days of incubation, the liquid culture was centrifuged at 13,000 rpm, $1 \mathrm{~mL}$ of supernatant was mixed with Salkowski's reagent, and the absorbance at $530 \mathrm{~nm}$ was determined.

To determine the production of siderophores, we followed a previously described method [131] for the initial screening. Briefly, Chrome Azurol S (CAS) agar was prepared using King's B medium as a basal medium [132]. After inoculation, the plates were incubated at $28{ }^{\circ} \mathrm{C}$ for 7 days, and the presence of an orange/yellow halozone was used as an indicator of siderophore production. To quantify siderophore production, actinobacteria were further grown in King's B liquid medium for 7 days at $28^{\circ} \mathrm{C}(140 \mathrm{rpm})$ and centrifuged at $13,000 \mathrm{rpm}$ to collect the supernatant. For hydroxamate siderophore production, the method of [133] was followed using desferrioxaminemesylate as standard. In brief, $0.5 \mathrm{~mL}$ of supernatant was mixed with $2.5 \mathrm{~mL}$ ferric perchlorate in the test tubes and incubated for $5 \mathrm{~min}$. The absorbance was measured at $480 \mathrm{~nm}$. Catecholate siderophore was determined by mixing the supernatant with $0.5 \mathrm{M} \mathrm{HCl} 1 \mathrm{~mL}$, Nitrite-molybdate reagent $1 \mathrm{~mL}$, and $1 \mathrm{M}$ $\mathrm{NaOH} 1 \mathrm{~mL}$. The mixture was incubated at room temperature for $5 \mathrm{~min}$, and the absorbance at $500 \mathrm{~nm}$ was determined using 2,3-dihydroxybenzoic acid as standard [134].

Phosphate solubilization ability was determined based on the presence and size of a clear zone on Pikovskaya (PVK) agar supplemented with $0.5 \%$ tricalcium phosphate [135].

\subsection{Evaluation of Antimicrobial Activities}

The agar plug assay [136] was used to evaluate the antimicrobial activities of actinobacteria from our moss samples. Specifically, a total of seven pathogenic microbial strains were used, including five bacterial pathogens and two fungal pathogens (one fungal pathogen was a yeast and the other was a filamentous fungus). The five bacterial pathogens were: (i) E. coli 15-318 (a multidrug-resistant (MDR) strain, resistant to a large number of drugs, such as gentamicin, ampicillin, and tetracycline. The full information of its drug susceptibility was reported by [137]); (ii) S. aureus ATCC 8923 (a wild-type, drug-susceptible strain); (iii) a methicillin-resistant S. aureus (MRSA)-43300; (iv) P. syringae pv. syringae 19874; and (v) P. aeruginosa 13. The human yeast pathogen was C. albicans 012 . For each of these five bacterial and one yeast pathogen, $10^{8}$ cells were individually spread on the agar surface in a Nunc ${ }^{\circledR}$ Bioassay plate $(24.5 \times 24.5 \times 2.5 \mathrm{~cm})$. Nutrient agar was used for bacterial pathogens and potato dextrose agar was used for C. albicans. Pure cultures of actinobacteria on Seino's Agar were incubated at $28^{\circ} \mathrm{C}$ for 30 days prior to the assay. An agar block of each actinobacteria isolate was prepared using a sterile spatula to cut the pure colony of actinobacteria in the size of $1 \times 1 \mathrm{~cm}$ then placed on the surface of the pathogen-seeded Nunc ${ }^{\circledR}$ Bioassay plate. The plate was incubated overnight, and the potential zone of inhibition was recorded. A sterile blank paper disk $(6 \mathrm{~mm})$ loaded with $20 \mu \mathrm{L}$ distilled water was used as a negative control. In addition, paper disks loaded with $20 \mu \mathrm{L} 10 \% \mathrm{NaClO}$ and $20 \mu \mathrm{L} 4.25 \% \mathrm{H}_{2} \mathrm{O}_{2}$, and BD BBL ${ }^{\mathrm{TM}}$ Sensi-Disc ${ }^{\mathrm{TM}}$ of $10 \mu \mathrm{g}$ Ampicillin, and $30 \mu \mathrm{g}$ tetracycline were used for the evaluation/confirmation of chemical and antibiotic resistance of strains of bacterial pathogens.

To evaluate the activities of actinobacterial strains against the filamentous fungal pathogen $P$. destructans, $10^{8}$ spores $/ \mathrm{mL}$ of P. destructans strain US15 (200 $\left.\mu \mathrm{L}\right)$ were spread on the surface of Sabouraud Dextrose Agar in a Nunc ${ }^{\circledR}$ Bioassay plate. Pure cultures of 
actinobacteria on Seino's Agar were incubated at $28^{\circ} \mathrm{C}$ for 30 days prior to the assay. An agar block of actinobacteria was prepared using a sterile needle to cut the pure colony of actinobacteria to the size of $1 \times 1 \mathrm{~cm}$ and placed on the surface of the Nunc ${ }^{\circledR}$ Bioassay plate. The bioassay plate was incubated at $15^{\circ} \mathrm{C}$ and the mycelial growth was observed after 14 days. A sterile blank paper disk loaded with $20 \mu \mathrm{L}$ distilled water was used as a negative control. Paper disks loaded with $20 \mu \mathrm{L} \mathrm{10 \%} \mathrm{NaClO}, 20 \mu \mathrm{L} 4.25 \% \mathrm{H}_{2} \mathrm{O}_{2}$, and $20 \mu \mathrm{L}$ $70 \% \mathrm{EtOH}$ were used for the determination of the chemical resistance of P. destructans.

The type of inhibition was determined following the criteria of [48]. Specifically, full inhibition against a pathogen means the complete inhibition with no microbial growth within a notable size zone of inhibition. In contrast, partial inhibition has weaker inhibition with some microbial growth in a relatively small zone of inhibition.

The pathogen stock cultures are maintained in the Cheeptham's Laboratory, Department of Biological Sciences, Thompson Rivers University, Canada.

\subsection{Identification of Actinobacteria from Mosses}

Actinobacteria were grouped according to the morphology and mycelia color that appeared on ISP2 and ISP3 agar [138]. Whole-cell polymerase chain reaction (PCR) was performed using GoTaq ${ }^{\circledR}$ Green Master Mix (Promega) following the manufacturer's instructions. 8F (5' AGAGTTTGATCCTGGCTCAG 3') and 1492R (5' GGTTACCTTGTTACGACTT $3^{\prime}$ ) universal primers were used to amplify the $16 \mathrm{~S}$ rRNA gene. PCR cycling condition was $95{ }^{\circ} \mathrm{C}$ for $5 \mathrm{~min}$, 35X $\left(95^{\circ} \mathrm{C}\right.$ for $30 \mathrm{~s}, 55^{\circ} \mathrm{C}$ for $30 \mathrm{~s}, 72{ }^{\circ} \mathrm{C}$ for $1.30 \mathrm{~min}$ ), $72{ }^{\circ} \mathrm{C}$ for $5 \mathrm{~min}$. $16 \mathrm{~S}$ rRNA sequencing was performed at the MOBIX lab at McMaster University, Canada. A sequence comparison of $16 \mathrm{~S}$ rRNA genes was achieved using the EzBiocloud database (https:/ /www.ezbiocloud.net/) (accessed on 30 November 2020). Sequence trimming and alignment were performed using the BioEdit Sequence Alignment Editor [139]. The neighbor-joining phylogenetic tree was constructed by MEGA7 [140] with 1000 bootstrap replications.

\subsection{GC-MS Analysis of Metabolites}

We selected three strains that showed significant antimicrobial activities for GC-MS analyses of their metabolites. To profile their secreted metabolites, we first grew these three strains (S32-76, S32-77, and S32-79) in Medium 400 [141] at $28{ }^{\circ} \mathrm{C}$ for 5 days at $140 \mathrm{rpm}$. The cells were precipitated through centrifugation. The crude culture supernatant $(50 \mathrm{~mL})$ of each isolate was taken and extracted three times with ethyl acetate at a 1:1 $(v / v)$ ratio. This mixture was shaken vigorously in a separating funnel, and the ethyl acetate layer was collected and evaporated in vacuo to dryness. The dried extract was dissolved in ethyl acetate $(10 \mathrm{mg} / \mathrm{mL})$ then transferred into a glass vial. Half of each sample was analyzed directly using GC-MS as described below. The other half was first derivatized before GC-MS analyses. For derivatization, $40 \mu \mathrm{L}$ of methoxyamination reagent (methoxyamine hydrochloride in pyridine at $20 \mathrm{mg} / \mathrm{mL})$ was added to each extract ( $\sim 3 \mathrm{mg}$ of dried extract). This mixture was vortexed and incubated at $37^{\circ} \mathrm{C}$, and after $2 \mathrm{~h}, 70 \mu \mathrm{L}$ of N-Methyl-N(trimethylsilyl)trifluoroacetamide (MSTFA) reagent was added. The mixture was vortexed again and incubated at $37^{\circ} \mathrm{C}$ for another $30 \mathrm{~min}$, and then centrifuged at $2000 \mathrm{rpm}$ ( $376 \mathrm{rcf}$ ) for $15 \mathrm{~min}$. The supernatant was transferred into a glass vial. The GC-MS profiles were analyzed using a GCMS-QP2020 NX (Shimadzu Co., Japan) equipped with an SH-Rxi-5Sil MS column $(0.25 \mu \mathrm{m} \mathrm{df} \times 0.25 \mathrm{~mm}$ ID $\times 30 \mathrm{~m}$ length). Helium $(99.9 \%)$ was used as the carrier gas at a flow rate of $1 \mathrm{~mL} / \mathrm{min}$. The sample was injected at a volume of $1 \mu \mathrm{L}$ using a split mode with a split ratio of 1:20. The ion source and interface temperature of the mass spectrometer, as well as the injector temperature, were maintained at $250{ }^{\circ} \mathrm{C}$. Mass spectra were obtained by electron ionization (EI) at $70 \mathrm{eV}$, using a mass scan range of $\mathrm{m} / \mathrm{z} 45-700$, with a scan speed of 2500. Detector gain and event time were $0.78+0.00 \mathrm{kV}$ and $0.3 \mathrm{~s}$, respectively. The column oven temperature program was set as follows: started at $60{ }^{\circ} \mathrm{C}$ (held for $3 \mathrm{~min}$ ) and raised at a rate of $8{ }^{\circ} \mathrm{C} / \mathrm{min}$ to $280^{\circ} \mathrm{C}$ (held for $25 \mathrm{~min}$ ). The compounds 
were identified by matching with the mass spectra in the NIST 17 database. Compounds having spectra that are more than $80 \%$ similar to those in the database were annotated.

\subsection{Bioassay of Secreted Extracellular Compounds against MRSA}

To analyze the potential antimicrobial activities of the secreted extracellular compounds, we choose the same three strains mentioned above (32-76, 32-77, and 32-79) that showed strong antimicrobial activities during plate assay. The three selected Streptomyces strains were subjected to small-scale fermentation by being inoculated in a $250 \mathrm{~mL}$ flask containing $100 \mathrm{~mL}$ of Medium 400. The strains were grown in shake flask conditions at $140 \mathrm{rpm}$ at $28^{\circ} \mathrm{C}$ for 5 days. Compound extraction methods were adapted from [142]. A total of $200 \mathrm{~mL}$ of cell-free supernatant from each strain was extracted with an equal volume of ethyl acetate for three times using a separation funnel. The crude extracts were dried by a rotary evaporator at $40{ }^{\circ} \mathrm{C}$ until they reached half of their volume. Then, the crude extracts were dried completely in a chemical hood. After the drying process, the crude extracts $(20 \mathrm{mg}$ ) were dissolved in $500 \mu \mathrm{L}$ absolute ethanol. For testing the potential antimicrobial activity of crude extracts, $40 \mu \mathrm{L}$ of crude extract from each strain was loaded onto a sterile $6 \mathrm{~mm}$ paper disk; we then waited until the disk was completely dry before placing it onto nutrient agar overlayed with an MRSA cell lawn. A paper disk loaded with $40 \mu \mathrm{L}$ absolute ethanol and then dried by air was used as a negative control.

\subsection{Statistical Analysis}

Statistical analysis of clear zones on PVK agar was performed by SPSS statistics 17.0 program.

\section{Conclusions}

In this study, the species of moss, culture medium, and pre-treatment condition all influenced the isolation of actinobacteria from mosses and from moss-associated rhizospheric soil. Our analyses revealed diverse actinobacteria associated with mosses in several genera, Streptomyces, Micromonospora, Nocardia, Actinoplanes, Saccharothrix, Streptosporangium, and Cryptosporangium. Many of these actinobacteria can produce IAA, siderophores, enzymes to solubilize tricalcium phosphate, antimicrobial compounds effective against plant pathogens, and signaling molecules for potential communication with other species. Indeed, GC-MS analyses indicated that several Streptomyces strains can produce a large number of bioactive compounds, including antimicrobials. Importantly, the actinobacteria from mosses can inhibit the growth of plant, human, and bat pathogens, including multidrug-resistant strains, demonstrating the significant potential for the discovery of novel antimicrobial agents. Together, our research suggests a number of avenues from which to further explore the roles of actinobacteria in drug discovery and in microbe-microbe and plant-microbe interactions [143].

Supplementary Materials: The following are available online at https://www.mdpi.com/article/10 .3390/metabo12010022/s1, Figure S1: GC-MS chromatogram of metabolites produced from actinobacteria; Table S1: Bioactive compounds identified by GC-MS of Streptomyces spp. ethyl acetate extract.

Author Contributions: Conceptualization, C.I. and W.P.-a.; methodology, C.I., A.F. and P.P.; software, C.I.; validation, C.I.; formal analysis, C.I.; investigation, C.I., N.C. and J.X.; resources, C.I.; data curation, C.I.; writing-original draft preparation, C.I.; writing-review and editing, N.C., W.P.-a. and J.X.; visualization, C.I.; supervision, W.P.-a., A.M., N.C. and J.X.; facility support in Japan, S.Ō. All authors have read and agreed to the published version of the manuscript.

Funding: CI was supported by the Development and Promotion of Science and Technology Talents Project (DPST), Ministry of Education, Thailand, and Canada-ASEAN Scholarships and Educational Exchanges for Development (SEED) program, supported by The Government of Canada. The APC was funded by the Global Science Initiative of McMaster University (2020-03).

Institutional Review Board Statement: Not applicable. 
Informed Consent Statement: Not applicable.

Data Availability Statement: Accession numbers for all 37 16S rRNA sequences used in this study can be found listed in Table 3 .

Acknowledgments: We appreciate the help of Narin Printarakul in moss identification and the help of Heather Yoell in DNA sequencing. Our sincere thanks also go to Akira Také, Yuki Inahashi, Timothy Crowe, Dipesh Prema, and Gabrielle Kam for their lab assistance.

Conflicts of Interest: The authors declare no conflict of interest.

\section{References}

1. Singh, R.; Dubey, A.K. Diversity and Applications of Endophytic Actinobacteria of Plants in Special and Other Ecological Niches. Front. Microbiol. 2018, 9, 1767. [CrossRef] [PubMed]

2. Qin, S.; Xing, K.; Jiang, J.-H.; Xu, L.-H.; Li, W.-J. Biodiversity, Bioactive Natural Products and Biotechnological Potential of Plant-Associated Endophytic Actinobacteria. Appl. Microbiol. Biotechnol. 2011, 89, 457-473. [CrossRef] [PubMed]

3. Golinska, P.; Wypij, M.; Agarkar, G.; Rathod, D.; Dahm, H.; Rai, M. Endophytic Actinobacteria of Medicinal Plants: Diversity and Bioactivity. Antonie van Leeuwenhoek 2015, 267-289. [CrossRef] [PubMed]

4. Zhao, J.; Shi, L.; Li, W.; Wang, J.; Wang, H.; Tian, Y.; Xiang, W.; Wang, X. Streptomyces tritici sp. nov., a Novel Actinomycete Isolated from Rhizosphere Soil of Wheat (Triticum aestivum L.). Int. J. Syst. Evol. Microbiol. 2018, 68, 492-497. [CrossRef] [PubMed]

5. Arunachalam Palaniyandi, S.; Yang, S.H.; Damodharan, K.; Suh, J.-W. Genetic and Functional Characterization of Culturable Plant-Beneficial Actinobacteria Associated with Yam Rhizosphere. J. Basic Microbiol. 2013, 53, 985-995. [CrossRef]

6. $\quad$ Carro, L.; Pukall, R.; Spröer, C.; Kroppenstedt, R.M.; Trujillo, M.E. Micromonospora cremea sp. nov. and Micromonospora zamorensis sp. nov., Isolated from the Rhizosphere of Pisum sativum. Int. J. Syst. Evol. Microbiol. 2012, 62((Pt. 12)), 2971-2977. [CrossRef]

7. Sathya, A.; Vijayabharathi, R.; Gopalakrishnan, S. Plant Growth-Promoting Actinobacteria: A New Strategy for Enhancing Sustainable Production and Protection of Grain Legumes. 3 Biotech 2017, 7, 102. [CrossRef]

8. Meschke, H.; Walter, S.; Schrempf, H. Characterization and Localization of Prodiginines from Streptomyces lividans Suppressing Verticillium dahliae in the Absence or Presence of Arabidopsis thaliana. Environ. Microbiol. 2012, 14, 940-952. [CrossRef]

9. Yandigeri, M.S.; Meena, K.K.; Singh, D.; Malviya, N.; Singh, D.P.; Solanki, M.K.; Yadav, A.K.; Arora, D.K. Drought-Tolerant Endophytic Actinobacteria Promote Growth of Wheat (Triticum aestivum) under Water Stress Conditions. Plant Growth Regul. 2012, 68, 411-420. [CrossRef]

10. Leontidou, K.; Genitsaris, S.; Papadopoulou, A.; Kamou, N.; Bosmali, I.; Matsi, T.; Madesis, P.; Vokou, D.; Karamanoli, K.; Mellidou, I. Plant Growth Promoting Rhizobacteria Isolated from Halophytes and Drought-Tolerant Plants: Genomic Characterisation and Exploration of Phyto-Beneficial Traits. Sci. Rep. 2020, 10, 14857. [CrossRef]

11. Jog, R.; Nareshkumar, G.; Rajkumar, S. Enhancing Soil Health and Plant Growth Promotion by Actinomycetes. In Plant Growth Promoting Actinobacteria: A New Avenue for Enhancing the Productivity and Soil Fertility of Grain Legumes; Subramaniam, G., Arumugam, S., Rajendran, V., Eds.; Springer: Singapore, 2016; pp. 33-45.

12. Insuk, C.; Kuncharoen, N.; Cheeptham, N.; Tanasupawat, S.; Pathom-Aree, W. Bryophytes Harbor Cultivable Actinobacteria With Plant Growth Promoting Potential. Front. Microbiol. 2020, 11, 563047. [CrossRef]

13. Liu, X.L.; Liu, S.L.; Liu, M.; Kong, B.H.; Liu, L.; Li, Y.H. A Primary Assessment of the Endophytic Bacterial Community in a Xerophilous Moss (Grimmia montana) Using Molecular Method and Cultivated Isolates. Braz. J. Microbiol. 2014, 45, 163-173. [CrossRef]

14. Turetsky, M.R.; Bond-Lamberty, B.; Euskirchen, E.; Talbot, J.; Frolking, S.; McGuire, A.D.; Tuittila, E.-S. The Resilience and Functional Role of Moss in Boreal and Arctic Ecosystems. New Phytol. 2012, 196, 49-67. [CrossRef]

15. Holland-Moritz, H.; Stuart, J.E.M.; Lewis, L.R.; Miller, S.N.; Mack, M.C.; Ponciano, J.M.; McDaniel, S.F.; Fierer, N. The Bacterial Communities of Alaskan Mosses and Their Contributions to N2-Fixation. Microbiome 2021, 9, 53. [CrossRef]

16. Hsing, W.; Canale-Parola, E. Cellobiose Chemotaxis by the Cellulolytic Bacterium Cellulomonas gelida. J. Bacteriol. 1992, 174, 7996-8002. [CrossRef]

17. Lamichhane, J.R.; Varvaro, L.; Parisi, L.; Audergon, J.-M.; Morris, C.E. Disease and Frost Damage of Woody Plants Caused by Pseudomonas syringae. Adv. Agron. 2014, 126, 235-295. [CrossRef]

18. Balestra, G.M.; Perestrelo, L.; Mazzaglia, A.; Rossetti, A. First Report of Blossom Blight Caused by Pseudomonas syringae on Kiwifruit Plants in Portugal. J. Plant Pathol. 2009, 91, 231.

19. Hall, B.H.; Cother, E.J.; Noble, D.; McMahon, R.; Wicks, T.J. First Report of Pseudomonas syringae on Olives (Olea europaea) in South Australia. Australas. Plant Pathol. 2003, 32, 119-120. [CrossRef]

20. Kotan, R.; Şahin, F. First Record of Bacterial Canker Caused by Pseudomonas syringae pv. syringae, on Apricot Trees in Turkey. Plant Pathol. 2002, 51, 798. [CrossRef]

21. Gutiérrez-Barranquero, J.A.; Cazorla, F.M.; de Vicente, A. Pseudomonas syringae pv. syringae Associated with Mango Trees, a Particular Pathogen within the "Hodgepodge" of the Pseudomonas syringae Complex. Front. Plant Sci. 2019, 10, 570. [CrossRef]

22. Sitaraman, R. Pseudomonas spp. as Models for Plant-Microbe Interactions. Front. Plant Sci. 2015, 6, 787. [CrossRef] 
23. Gao, J.; Wang, Y.; Wang, C.W.; Lu, B.H. First Report of Bacterial Root Rot of Ginseng Caused by Pseudomonas aeruginosa in China. Plant Dis. 2014, 98, 1577. [CrossRef]

24. Walker, T.S.; Bais, H.P.; Déziel, E.; Schweizer, H.P.; Rahme, L.G.; Fall, R.; Vivanco, J.M. Pseudomonas aeruginosa-Plant Root Interactions. Pathogenicity, Biofilm Formation, and Root Exudation. Plant Physiol. 2004, 134, 320-331. [CrossRef]

25. Huang, C.J.; Lin, C.H. First Report of Pseudomonas aeruginosa Causing Internal Brown Rot of Stored Onion Bulbs in Taiwan. J. Plant Pathol. 2017, 99, 817.

26. Frank, C.L.; Davis, A.D.; Herzog, C. The Evolution of a Bat Population with White-Nose Syndrome (WNS) Reveals a Shift from an Epizootic to an Enzootic Phase. Front. Zool. 2019, 16, 40. [CrossRef]

27. Boyles, J.G.; Cryan, P.M.; McCracken, G.F.; Kunz, T.H. Conservation. Economic Importance of Bats in Agriculture. Science 2011, 332, 41-42. [CrossRef]

28. Medina, E.; Pieper, D.H. Tackling Threats and Future Problems of Multidrug-Resistant Bacteria. Curr. Top. Microbiol. Immunol. 2016, 398, 3-33.

29. Saitou, N.; Nei, M. The Neighbor-Joining Method: A New Method for Reconstructing Phylogenetic Trees. Mol. Biol. Evol. 1987, 4, 406-425. [CrossRef]

30. Tamura, K.; Nei, M.; Kumar, S. Prospects for Inferring Very Large Phylogenies by Using the Neighbor-Joining Method. Proc. Natl. Acad. Sci. USA 2004, 101, 11030-11035. [CrossRef]

31. Asghari, G.; Jalali, M.; Sadoughi, E. Antimicrobial Activity and Chemical Composition of Essential Oil from the Seeds of Artemisia aucheri Boiss. Jundishapur J. Nat. Pharm. Prod. 2012, 7, 11-15. [CrossRef]

32. Lilley, B.D.; Brewer, J.H. The Selective Antibacterial Action of Phenylethyl Alcohol. J. Am. Pharm. Assoc. 1953, 42, 6-8. [CrossRef] [PubMed]

33. Narendhran, S.; Rajiv, P.; Vanathi, P.; Sivaraj, R. Spectroscopic Analysis of Bioactive Compounds from Streptomyces cavouresis KUV39: Evaluation of Antioxidant and Cytotoxicity Activity. Int. J. Pharm. Pharm. Sci. 2014, 6, 319-322.

34. Naeim, H.; El-Hawiet, A.; Abdel Rahman, R.A.; Hussein, A.; El Demellawy, M.A.; Embaby, A.M. Antibacterial Activity of Centaurea pumilio L. Root and Aerial Part Extracts against Some Multidrug Resistant Bacteria. BMC Complement. Med. Ther. 2020, 20, 79. [CrossRef] [PubMed]

35. Falade, O.E.; Oyetayo, V.O.; Awala, S.I. Evaluation of the Mycochemical Composition and Antimicrobial Potency of Wild Macrofungus, Rigidoporus microporus (Sw). J. Phytopharm. 2017, 6, 115-125. [CrossRef]

36. Kumari, N.; Menghani, E.; Mithal, R. GCMS Analysis of Compounds Extracted from Actinomycetes AIA6 Isolates and Study of Its Antimicrobial Efficacy. Indian J. Chem. Technol. 2019, 26, 362-370.

37. Judzentiene, A.; Budiene, J.; Svediene, J.; Garjonyte, R. Toxic, Radical Scavenging, and Antifungal Activity of Rhododendron tomentosum H. Essential Oils. Molecules 2020, 25, 1676. [CrossRef]

38. Dinesh, M.; Deepika, S.; HarishKumar, R.; Selvaraj, C.I.; Roopan, S.M. Evaluation of Octyl- $\beta$-D-Glucopyranoside (OGP) for Cytotoxic, Hemolytic, Thrombolytic, and Antibacterial Activity. Appl. Biochem. Biotechnol. 2018, 185, 450-463. [CrossRef]

39. Bratty, M.A.; Al Bratty, M.; Makeen, H.A.; Alhazmi, H.A.; Syame, S.M.; Abdalla, A.N.; Homeida, H.E.; Sultana, S.; Ahsan, W.; Khalid, A. Phytochemical, Cytotoxic, and Antimicrobial Evaluation of the Fruits of Miswak Plant, Salvadora persica L. J. Chem. 2020, 2020, 4521951. [CrossRef]

40. Liu, H.; Huang, J.; Yang, S.; Li, J.; Zhou, L. Chemical Composition, Algicidal, Antimicrobial, and Antioxidant Activities of the Essential Oils of Taiwania flousiana Gaussen. Molecules 2020, 25, 967. [CrossRef]

41. Dunkić, V.; Kosalec, I.; Kosir, I.J.; Potocnik, T.; Cerenak, A.; Koncic, M.Z.; Vitali, D.; Muller, I.D.; Kopricanec, M.; Bezic, N.; et al Antioxidant and Antimicrobial Properties of Veronica spicata L. (Plantaginaceae). Curr. Drug Targets 2015, 16, 1660-1670. [CrossRef]

42. Nafis, A.; Kasrati, A.; Jamali, C.A.; Custódio, L.; Vitalini, S.; Iriti, M.; Hassani, L. A Comparative Study of the in vitro Antimicrobial and Synergistic Effect of Essential Oils from Laurus nobilis L. and Prunus armeniaca L. from Morocco with Antimicrobial Drugs: New Approach for Health Promoting Products. Antibiotics 2020, 9, 140. [CrossRef]

43. Shanthakumar, S.P.; Duraisamy, P.; Vishwanath, G.; Selvanesan, B.C.; Ramaraj, V.; Vasantharaj David, B. Broad Spectrum Antimicrobial Compounds from the Bacterium Exiguobacterium mexicanum MSSRFS9. Microbiol. Res. 2015, 178, 59-65. [CrossRef]

44. Tasco, A.J.H.; Rueda, R.Y.R.; Alvarez, C.J.; Sartori, F.T.; Sacilotto, A.C.B.; Ito, I.Y.; Vichnewski, W.; Salvador, M.J. Antibacterial and Antifungal Properties of Crude Extracts and Isolated Compounds from Lychnophora markgravii. Nat. Prod. Res. 2020, 34, 863-867. [CrossRef]

45. Alhazmi, H.A.; Sultana, S.; Khan, A.; Al-Bratty, M. GC-MS Analysis and Antimicrobial Activity of Ethanolic Extract of Calotropis procera (Ait.) R. Br. Leaves. J. Chem. Pharm. Res. 2018, 10, 45-49.

46. Ravi, R.; Zulkrnin, N.S.H.; Rozhan, N.N.; Yusoff, N.R.N.; Rasat, M.S.M.; Ahmad, M.I.; Hamzah, Z.; Ishak, I.H.; Amin, M.F.M. Evaluation of Two Different Solvents for Azolla pinnata Extracts on Chemical Compositions and Larvicidal Activity against Aedes albopictus (Diptera: Culicidae). J. Chem. 2018, 2018, 7453816. [CrossRef]

47. Osuntokun, O.T.; Cristina, G.M. Bio Isolation, Chemical Purification, Identification, Antimicrobial and Synergistic Efficacy of Extracted Essential Oils from Stem Bark Extract of Spondias mombin (Linn). Int. J. Mol. Biol. 2019, 4, 135-143. [CrossRef]

48. Sengupta, S.; Nandi, I.; Bhattacharyya, D.K.; Ghosh, M. Anti-Oxidant and Anti-Bacterial Properties of 1-Octacosanol Isolated from Rice Bran Wax. J. Plant Biochem. Physiol. 2018, 6, 2. [CrossRef] 
49. Swamy, M.K.; Arumugam, G.; Kaur, R.; Ghasemzadeh, A.; Yusoff, M.M.; Sinniah, U.R. GC-MS Based Metabolite Profiling, Antioxidant and Antimicrobial Properties of Different Solvent Extracts of Malaysian Leaves. Evid.-Based. Complement. Alternat. Med. 2017, 2017, 1517683. [CrossRef]

50. Değirmenci, H.; Erkurt, H. Relationship between Volatile Components, Antimicrobial and Antioxidant Properties of the Essential Oil, Hydrosol and Extracts of Citrus aurantium L. Flowers. J. Infect. Public Health 2020, 13, 58-67. [CrossRef]

51. Vinuchakkaravarthy, T.; Kumaravel, K.P.; Ravichandran, S.; Velmurugan, D. Active Compound from the Leaves of Vitex Negundo L. Shows Anti-Inflammatory Activity with Evidence of Inhibition for Secretory Phospholipase A(2) through Molecular Docking Bioinformation 2011, 7, 199-206. [CrossRef]

52. De Guzman Alvindia, D.; Mangoba, M.A.A. Bioactivities of Allium longicuspis Regel against Anthracnose of Mango Caused by Colletotrichum gloeosporioides (Penz.). Sci. Rep. 2020, 10, 11367. [CrossRef]

53. Yassin, M.T.; Mostafa, A.A.; Al-Askar, A.A. Anticandidal and Anti-Carcinogenic Activities of Mentha longifolia (Wild Mint) Extracts in vitro. J. King Saud Univ.-Sci. 2020, 32, 2046-2052. [CrossRef]

54. Segueni, N.; Zellagui, A.; Boulechfar, S.; Derouiche, K.; Rhouati, S. Essential Oil of Hertia cheirifolia Leaves: Chemical Composition, Antibacterial and Antioxidant Activities. J. Mater. Environ. Sci. 2017, 8, 551-556.

55. Mar, A.; Pripdeevech, P. Chemical Composition and Antibacterial Activity of Essential Oil and Extracts of Citharexylum spinosum Flowers from Thailand. Nat. Prod. Commun. 2014, 9, 707-710. [CrossRef]

56. Guzmán-López, O.; Trigos, Á.; Fernández, F.J.; de Jesús Yañez-Morales, M.; Saucedo-Castañeda, G. Tyrosol and Tryptophol Produced by Ceratocystis adiposa. World J. Microbiol. Biotechnol. 2007, 23, 1473-1477. [CrossRef]

57. Mujeeb, F.; Bajpai, P.; Pathak, N. Phytochemical Evaluation, Antimicrobial Activity, and Determination of Bioactive Components from Leaves of Aegle marmelos. Biomed Res. Int. 2014, 2014, 497606. [CrossRef]

58. Faridha Begum, I.; Mohankumar, R.; Jeevan, M.; Ramani, K. GC-MS Analysis of Bio-Active Molecules Derived from FMR19 and the Antimicrobial Activity Against Bacterial Pathogens and MDROs. Indian J. Microbiol. 2016, 56, 426-432. [CrossRef]

59. Weinstein, L. The Action of Urea and Some of Its Derivatives on Bacteria; the Effect of Combining Urea or Urethane with Penicillin on Mixed Cultures of Gram-Positive and Gram-Negative Bacteria. J. Immunol. 1946, 54, 145-149.

60. Zhang, J.-L.; Yao, J.; Zhuge, J.-N.; Zhang, Y.-J. Antibacterial Activity of Erythritol on Periodontal Pathogen. Shanghai Kou Qiang Yi Xue 2019, 28, 362-367. [PubMed]

61. Loimaranta, V.; Mazurel, D.; Deng, D.; Söderling, E. Xylitol and Erythritol Inhibit Real-Time Biofilm Formation of Streptococcus mutans. BMC Microbiol. 2020, 20, 184. [CrossRef] [PubMed]

62. Luo, L.; Kim, S.-W.; Lee, H.-K.; Kim, I.-D.; Lee, H.; Lee, J.-K. Anti-Oxidative Effects of 4-Hydroxybenzyl Alcohol in Astrocytes Confer Protective Effects in Autocrine and Paracrine Manners. PLoS ONE 2017, 12, e0177322. [CrossRef] [PubMed]

63. Yue, X.-F.; Shang, X.; Zhang, Z.-J.; Zhang, Y.-N. Phytochemical Composition and Antibacterial Activity of the Essential Oils from Different Parts of Sea Buckthorn (Hippophae rhamnoides L.). J. Food Drug Anal. 2017, 25, 327-332. [CrossRef] [PubMed]

64. Radmerikhi, S.; Formantes, B.; Fajardo, K.R.; Azul, E. Antimicrobial Effect of Different Xylitol Concentrations on Streptococcus mutans and Lactobacillus acidophilus Count. J. Restor. Dent. 2013, 1, 95. [CrossRef]

65. Tapiainen, T.; Kontiokari, T.; Sammalkivi, L.; Ikäheimo, I.; Koskela, M.; Uhari, M. Effect of Xylitol on Growth of Streptococcus pneumoniae in the Presence of Fructose and Sorbitol. Antimicrob. Agents Chemother. 2001, 45, 166-169. [CrossRef]

66. Bellaire, B.H.; Elzer, P.H.; Baldwin, C.L.; Roop, R.M., II. Production of the Siderophore 2,3-Dihydroxybenzoic Acid Is Required for Wild-Type Growth of Brucella abortus in the Presence of Erythritol under Low-Iron Conditions in Vitro. Infect. Immun. 2003, 71, 2927-2932. [CrossRef]

67. George, S.; Benny, P.J.; Kuriakose, S.; George, C. Antibiotic Activity of 2, 3-Dihydroxybenzoic Acid Isolated from Flacourtia inermis Fruit against Multidrug Resistant Bacteria. Asian J. Pharm. Clin. Res. 2011, 4, 126-130.

68. Chen, X.; Zhao, X.; Deng, Y.; Bu, X.; Ye, H.; Guo, N. Antimicrobial Potential of Myristic Acid against Listeria monocytogenes in Milk. J. Antibiot. 2019, 72, 298-305. [CrossRef]

69. Agoramoorthy, G.; Chandrasekaran, M.; Venkatesalu, V.; Hsu, M.J. Antibacterial and Antifungal Activities of Fatty Acid Methyl Esters of the Blind-Your-Eye Mangrove from India. Braz. J. Microbiol. 2007, 38, 739-742. [CrossRef]

70. Widyowati, R.; Agil, M. Chemical Constituents and Bioactivities of Several Indonesian Plants Typically Used in Jamu. Chem. Pharm. Bull. 2018, 66, 506-518. [CrossRef]

71. Musa, A.M.; Ibrahim, M.A.; Aliyu, A.B.; Abdullahi, M.S.; Tajuddeen, N.; Ibrahim, H.; Oyewale, A.O. Chemical Composition and Antimicrobial Activity of Hexane Leaf Extract of Anisopus mannii (Asclepiadaceae). J. Intercult. Ethnopharmacol. 2015, 4, 129-133. [CrossRef]

72. Nguyen, X.H.; Naing, K.W.; Lee, Y.S.; Kim, Y.H.; Moon, J.H.; Kim, K.Y. Antagonism of Antifungal Metabolites from Streptomyces griseus H7602 against Phytophthora capsici. J. Basic Microbiol. 2015, 55, 45-53. [CrossRef]

73. Al-Dhabi, N.A.; Esmail, G.A.; Ghilan, A.-K.M.; Arasu, M.V.; Duraipandiyan, V.; Ponmurugan, K. Chemical Constituents of Streptomyces sp. Strain Al-Dhabi-97 Isolated from the Marine Region of Saudi Arabia with Antibacterial and Anticancer Properties. J. Infect. Public Health 2020, 13, 235-243. [CrossRef]

74. Azizan, K.A.; Ghani, N.H.A.; Nawawi, M.F. GC-MS Based Metabolomics and Multivariate Statistical Analysis of Wedelia trilobata Extracts for the Identification of Potential Phytochemical Properties. Plant Omics J. 2015, 8, 537-543.

75. Purohit, A.; Mohan, A. Antimicrobial Effects of Pyruvic and Succinic Acids on Salmonella Survival in Ground Chicken. LWT 2019, 116, 108596. [CrossRef] 
76. Balachandran, C.; Duraipandiyan, V.; Ignacimuthu, S. Cytotoxic (A549) and Antimicrobial Effects of Methylobacterium sp. Isolate (ERI-135) from Nilgiris Forest Soil, India. Asian Pac. J. Trop. Biomed. 2012, 2, 712-716. [CrossRef]

77. Saadouli, I.; Zendah El Euch, I.; Trabelsi, E.; Mosbah, A.; Redissi, A.; Ferjani, R.; Fhoula, I.; Cherif, A.; Sabatier, J.-M.; Sewald, N.; et al. Isolation, Characterization and Chemical Synthesis of Large Spectrum Antimicrobial Cyclic Dipeptide (1-Leu-L-Pro) from V16R3Y1 Bacteria Extracts. A Novel H NMR Metabolomic Approach. Antibiotics 2020, 9, 270. [CrossRef]

78. Demirci, M.A.; Ipek, Y.; Gul, F.; Ozen, T.; Demirtas, I. Extraction, Isolation of Heat-Resistance Phenolic Compounds, Antioxidant Properties, Characterization and Purification of 5-Hydroxymaltol from Turkish Apple Pulps. Food Chem. 2018, 269, 111-117. [CrossRef]

79. Matsumoto, A.; Takahashi, Y. Endophytic Actinomycetes: Promising Source of Novel Bioactive Compounds. J. Antibiot. 2017, 70, 514-519. [CrossRef]

80. Tyler, T.; Olsson, P.A. Substrate pH Ranges of South Swedish bryophytes-Identifying Critical pH Values and Richness Patterns. Flora 2016, 223, 74-82. [CrossRef]

81. Wang, C.-Y.; Zhou, X.; Guo, D.; Zhao, J.-H.; Yan, L.; Feng, G.-Z.; Gao, Q.; Yu, H.; Zhao, L.-P. Soil pH Is the Primary Factor Driving the Distribution and Function of Microorganisms in Farmland Soils in Northeastern China. Ann. Microbiol. 2019, 69, 1461-1473. [CrossRef]

82. El-Tarabily, K.A.; Sivasithamparam, K. Non-Streptomycete Actinomycetes as Biocontrol Agents of Soil-Borne Fungal Plant Pathogens and as Plant Growth Promoters. Soil Biol. Biochem. 2006, 38, 1505-1520. [CrossRef]

83. Fang, B.-Z.; Salam, N.; Han, M.-X.; Jiao, J.-Y.; Cheng, J.; Wei, D.-Q.; Xiao, M.; Li, W.-J. Insights on the Effects of Heat Pretreatment, $\mathrm{pH}$, and Calcium Salts on Isolation of Rare Actinobacteria from Karstic Caves. Front. Microbiol. 2017, 8, 1535. [CrossRef] [PubMed]

84. Intra, B.; Mungsuntisuk, I.; Nihira, T.; Igarashi, Y.; Panbangred, W. Identification of Actinomycetes from Plant Rhizospheric Soils with Inhibitory Activity against Colletotrichum spp., the Causative Agent of Anthracnose Disease. BMC Res. Notes $2011,4,98$. [CrossRef] [PubMed]

85. Masand, M.; Jose, P.A.; Menghani, E.; Jebakumar, S.R.D. Continuing Hunt for Endophytic Actinomycetes as a Source of Novel Biologically Active Metabolites. World J. Microbiol. Biotechnol. 2015, 31, 1863-1875. [CrossRef]

86. Qin, S.; Bian, G.-K.; Zhang, Y.-J.; Xing, K.; Cao, C.-L.; Liu, C.-H.; Dai, C.-C.; Li, W.-J.; Jiang, J.-H. Modestobacter roseus sp. nov., an Endophytic Actinomycete Isolated from the Coastal Halophyte Salicornia europaea Linn., and Emended Description of the Genus Modestobacter. Int. J. Syst. Evol. Microbiol. 2013, 63((Pt. 6)), 2197-2202. [CrossRef]

87. Passari, A.K.; Chandra, P.; Zothanpuia; Mishra , V.K.; Leo, V.V.; Gupta, V.K.; Kumar, B.; Singh, B.P. Detection of Biosynthetic Gene and Phytohormone Production by Endophytic Actinobacteria Associated with Solanum lycopersicum and Their Plant-GrowthPromoting Effect. Res. Microbiol. 2016, 167, 692-705. [CrossRef]

88. Shutsrirung, A.; Chromkaew, Y.; Pathom-Aree, W.; Choonluchanon, S.; Boonkerd, N. Diversity of Endophytic Actinomycetes in Mandarin Grown in Northern Thailand, Their Phytohormone Production Potential and Plant Growth Promoting Activity. Soil Sci. Plant Nutr. 2013, 59, 322-330. [CrossRef]

89. Wang, W.; Qiu, Z.; Tan, H.; Cao, L. Siderophore Production by Actinobacteria. Biometals 2014, 27, 623-631. [CrossRef]

90. Aznar, A.; Dellagi, A. New Insights into the Role of Siderophores as Triggers of Plant Immunity: What Can We Learn from Animals? J. Exp. Bot. 2015, 66, 3001-3010. [CrossRef]

91. Schrettl, M.; Bignell, E.; Kragl, C.; Sabiha, Y.; Loss, O.; Eisendle, M.; Wallner, A.; Arst, H.N., Jr.; Haynes, K.; Haas, H. Distinct Roles for Intra- and Extracellular Siderophores during Aspergillus fumigatus Infection. PLoS Pathog. 2007, 3, 1195-1207. [CrossRef]

92. Nimnoi, P.; Pongsilp, N.; Lumyong, S. Endophytic Actinomycetes Isolated from Aquilaria crassna Pierre Ex Lec and Screening of Plant Growth Promoters Production. World J. Microbiol. Biotechnol. 2010, 26, 193-203. [CrossRef]

93. Backer, R.; Rokem, J.S.; Ilangumaran, G.; Lamont, J.; Praslickova, D.; Ricci, E.; Subramanian, S.; Smith, D.L. Plant GrowthPromoting Rhizobacteria: Context, Mechanisms of Action, and Roadmap to Commercialization of Biostimulants for Sustainable Agriculture. Front. Plant Sci. 2018, 9, 1473. [CrossRef]

94. Hamdali, H. Isolation and Characterization of Rock Phosphate Solubilizing Actinobacteria from a Togolese Phosphate Mine. Afr J. Biotechnol. 2011, 11, 312-320. [CrossRef]

95. Passari, A.K.; Mishra, V.K.; Singh, G.; Singh, P.; Kumar, B.; Gupta, V.K.; Sarma, R.K.; Saikia, R.; Donovan, A.O.; Singh, B.P. Insights into the Functionality of Endophytic Actinobacteria with a Focus on Their Biosynthetic Potential and Secondary Metabolites Production. Sci. Rep. 2017, 7, 11809. [CrossRef]

96. Gulati, A.; Sharma, N.; Vyas, P.; Sood, S.; Rahi, P.; Pathania, V.; Prasad, R. Organic Acid Production and Plant Growth Promotion as a Function of Phosphate Solubilization by Acinetobacter rhizosphaerae Strain BIHB 723 Isolated from the Cold Deserts of the Trans-Himalayas. Arch. Microbiol. 2010, 192, 975-983. [CrossRef]

97. Ghods, S.; Sims, I.M.; Moradali, M.F.; Rehm, B.H.A. Bactericidal Compounds Controlling Growth of the Plant Pathogen Pseudomonas syringae pv. actinidiae, Which Forms Biofilms Composed of a Novel Exopolysaccharide. Appl. Environ. Microbiol. 2015, 81, 4026-4036. [CrossRef]

98. Keser, S.; Mutlu, M.B.; Güven, K. Antimicrobial Effect of Halophilic Actinomycetes on Xanthomonas and Pseudomonas Tomato Disease Agents. II Int. Symp. Tomato Dis. 2007, 808, 401-404. [CrossRef]

99. Nedialkova, D.; Naidenova, M. Screening the Antimicrobial Activity of Actinomycetes Strains Isolated from Antarctica. J. Cult. Collect. 2005, 4, 29-35. 
100. Micalizzi, E.W.; Mack, J.N.; White, G.P.; Avis, T.J.; Smith, M.L. Microbial Inhibitors of the Fungus Pseudogymnoascus destructans, the Causal Agent of White-Nose Syndrome in Bats. PLoS ONE 2017, 12, e0179770. [CrossRef]

101. Li, C.; Jin, P.; Liu, C.; Ma, Z.; Zhao, J.; Li, J.; Wang, X.; Xiang, W. Streptomyces bryophytorum sp. nov., an Endophytic Actinomycete Isolated from Moss (Bryophyta). Antonie Van Leeuwenhoek 2016, 109, 1209-1215. [CrossRef]

102. Suriyachadkun, C.; Ngaemthao, W.; Pujchakarn, T.; Chunhametha, S. Cryptosporangium phraense sp. nov., Isolated from Plant Litter. Int. J. Syst. Evol. Microbiol. 2020, 70, 971-976. [CrossRef]

103. Nurkanto, A.; Lisdiyanti, P.; Hamada, M.; Ratnakomala, S.; Shibata, C.; Tamura, T. Cryptosporangium cibodasense sp. nov., Isolated from Leaf Litter in Indonesia. Int. J. Syst. Evol. Microbiol. 2015, 65, 4632-4637. [CrossRef]

104. Himaman, W.; Suksaard, P.; Mingma, R.; Matsumoto, A.; Duangmal, K. Cryptosporangium eucalypti sp. nov., an Actinomycete Isolated from Eucalyptus camaldulensis Roots. Int. J. Syst. Evol. Microbiol. 2017, 67, 3077-3082. [CrossRef]

105. Zitouni, A.; Lamari, L.; Boudjella, H.; Badji, B.; Sabaou, N.; Gaouar, A.; Mathieu, F.; Lebrihi, A.; Labeda, D.P. Saccharothrix algeriensis sp. nov., Isolated from Saharan Soil. Int. J. Syst. Evol. Microbiol 2004, 54((Pt. 4)), 1377-1381. [CrossRef]

106. Liu, C.; Guan, X.; Wang, S.; Zhao, J.; Wang, H.; He, H.; Xiang, W.; Wang, X. Saccharothrix carnea sp. nov., an Actinobacterium Isolated from Soil. Int. J. Syst. Evol. Microbiol. 2014, 64, 4033-4037. [CrossRef]

107. Zhang, L.-P.; Jiang, C.-L.; Chen, W.-X. Streptosporangium yunnanense sp. nov. and Streptosporangium purpuratum sp. nov., from Soil in China. Int. J. Syst. Evol. Microbiol. 2005, 55 Pt 2, 719-724. [CrossRef]

108. Zhao, J.; Guo, L.; Li, Z.; Piao, C.; Li, Y.; Li, J.; Liu, C.; Wang, X.; Xiang, W. Streptosporangium jiaoheense sp. nov. and Streptosporangium taraxaci sp. nov., Actinobacteria Isolated from Soil and Dandelion Root (Taraxacum mongolicum Hand.-Mazz.). Int. J. Syst. Evol. Microbiol. 2016, 66, 2370-2376. [CrossRef] [PubMed]

109. Ara, I.; Yamamura, H.; Tsetseg, B.; Daram, D.; Ando, K. Actinoplanes toevensis sp. nov. and Actinoplanes tereljensis sp. nov., Isolated from Mongolian Soil. Int. J. Syst. Evol. Microbiol. 2010, 60((Pt. 4)), 919-927. [CrossRef] [PubMed]

110. Sazak, A.; Sahin, N.; Camas, M. Actinoplanes abujensis sp. nov., Isolated from Nigerian Arid Soil. Int. J. Syst. Evol. Microbiol. 2012, 62 (Pt. 4), 960-965. [CrossRef] [PubMed]

111. Borsetto, C.; Amos, G.C.A.; da Rocha, U.N.; Mitchell, A.L.; Finn, R.D.; Laidi, R.F.; Vallin, C.; Pearce, D.A.; Newsham, K.K.; Wellington, E.M.H. Microbial Community Drivers of PK/NRP Gene Diversity in Selected Global Soils. Microbiome $2019,7,78$. [CrossRef]

112. Yu, D.; Xu, F.; Zeng, J.; Zhan, J. Type III Polyketide Synthases in Natural Product Biosynthesis. IUBMB Life 2012, 64, $285-295$. [CrossRef]

113. Miller, K.I.; Qing, C.; Sze, D.M.Y.; Neilan, B.A. Investigation of the Biosynthetic Potential of Endophytes in Traditional Chinese Anticancer Herbs. PLoS ONE 2012, 7, e35953. [CrossRef]

114. Chen, F.; Ludwiczuk, A.; Wei, G.; Chen, X.; Crandall-Stotler, B.; Bowman, J.L. Terpenoid Secondary Metabolites in Bryophytes: Chemical Diversity, Biosynthesis and Biological Functions. CRC Crit. Rev. Plant Sci. 2018, 37, 210-231. [CrossRef]

115. Vinuchakkaravarthy, T.; Sangeetha, C.K.; Velmurugan, D. Tris(2,4-Di-Tert-Butyl-Phen-Yl) Phosphate. Acta Crystallogr. Sect. E Struct. Rep. Online 2010, 66 (Pt. 9), o2207-o2208. [CrossRef]

116. Janso, J.E.; Carter, G.T. Biosynthetic Potential of Phylogenetically Unique Endophytic Actinomycetes from Tropical Plants. Appl. Environ. Microbiol. 2010, 76, 4377-4386. [CrossRef]

117. Jones, S.E.; Pham, C.A.; Zambri, M.P.; McKillip, J.; Carlson, E.E.; Elliot, M.A. Streptomyces Volatile Compounds Influence Exploration and Microbial Community Dynamics by Altering Iron Availability. mBio 2019, 10, e00171-19. [CrossRef]

118. Wu, P.C.; Wang, M.Z. Polytrichaceae. In Moss Flora of China; He, S., Ed.; Missouri Botanical Garden Press: St. Louis, MO, USA, 2005; Volume 8, pp. 306-366.

119. Eddy, A. A Handbook of Malesian Mosses; British Museum (Natural History): London, UK, 1988.

120. Zhang, M.X.; He, S. Hypnaceae. In Moss Flora of China; He, S., Ed.; Missouri Botanical Garden Press: St. Louis, MO, USA, 2005; Volume 8, pp. 80-260.

121. Gangulee, H.C. Mosses of Eastern India and Adjacent Regions; University of Culcutta: Culcutta, India, 1969.

122. Touw, A. A Taxonomic Revision of the Thuidiaceae (Musci) of Tropical Asia, the Western Pacific, and Hawaii. J. Hattori Bot. Lab. 2001, 91, 1-136.

123. Li, X.J.; He, S.; Zang, M.; Missouri Botanical Garden Press:, St. Moss Flora of China; Missouri Botanical Garden Press: St. Louis, MO, USA, 2007; Volume 4.

124. Noguchi, A. A Revision of the Genus Macrothamnium M. Fleisch. (Musci). Kumamoto J. Sci. Biol. 1972, 11, 1-12.

125. Noguchi, A. Illustrated Moses Flora of Japan, Part 3. J. Hattori Bot. Lab. 1989, 3, 493-742.

126. Ignatov, M.S.; Huttunen, S.; Koponen, T. Bryophyte Flora of Hunan Province, China. 5. Brachytheciaceae (Musci), with an Overview of Eurhynchiadelphus and Rhynchostegiella in South-East Asia. Acta Bot. Fenn. 2005, 178, 1-56.

127. Wang, Y.F.; Hu, R.L. Brachytheciaceae. In Moss Flora of China; He, S., Ed.; Missouri Botanical Garden Press: St. Louis, MO, USA, 2008; Volume 7, pp. 71-167.

128. Dabek-Szremiawska, M.; Hattori, T. Winogradsky's Salts Solution as a Diluting Medium for Plate Count of Oligotrophic Bacteria in Soil. J. Gen. Appl. Microbiol. 1981, 27, 517-518. [CrossRef]

129. Inter-Society Color Council; Kelly, K.L. ISCC-NBS Color-Name Charts Illustrated with Centroid Colors; National Bureau of Standards: Washington, DC, USA, 1965. 
130. Glickmann, E.; Dessaux, Y. A Critical Examination of the Specificity of the Salkowski Reagent for Indolic Compounds Produced by Phytopathogenic Bacteria. Appl. Environ. Microbiol. 1995, 61, 793-796. [CrossRef]

131. Schwyn, B.; Neilands, J.B. Universal Chemical Assay for the Detection and Determination of Siderophores. Anal. Biochem. 1987, 160, 47-56. [CrossRef]

132. King, E.O.; Ward, M.K.; Rangey, D.E. Two Simple Media for Demonstrate of Pyocyanin and Fluorescei. J. Lab. Clin. Med. 1954, 44, 301-307.

133. Atkin, C.L.; Neilands, J.B.; Phaff, H.J. Rhodotorulic Acid from Species of Leucosporidium, Rhodosporidium, Rhodotorula, Sporidiobolus, and Sporobolomyces, and a New Alanine-Containing Ferrichrome from Cryptococcus melibiosum. J. Bacteriol. 1970, 103, 722-733. [CrossRef]

134. Arnow, L.E. Colorimetric Determination of the Components of 3,4-Dihydroxyphenylalaninetyrosine Mixtures. J. Biol. Chem. 1937, 118, 531-537. [CrossRef]

135. Nautiyal, C.S. An Efficient Microbiological Growth Medium for Screening Phosphate Solubilizing Microorganisms. FEMS Microbiol. Lett. 1999, 170, 265-270. [CrossRef]

136. McArthur, R.L.; Ghosh, S.; Cheeptham, N. Improvement of Protocols for the Screening of Biological Control Agents against White-Nose Syndrome. J. Exp. Microbiol. Immunol. 2017, 2, 1-7.

137. Ghosh, S.; Persad, E.; Shiue, T.-Y.; Lam, C.; Islam, A.; Mascibroda, L.G.; Sherman, M.B.; Smith, T.; Cheeptham, N. Explorative Study on Isolation and Characterization of a Microviridae G4 Bacteriophage, EMCL318, against Multi-Drug-Resistant Escherichia coli 15-318. Antibiotics 2018, 7, 92. [CrossRef]

138. Shirling, E.B.; Gottlieb, D. Methods for Characterization of Streptomyces Species. Int. J. Syst. Bacteriol. 1966, 16, 313-340. [CrossRef]

139. Alzohairy, A.M. BioEdit: An Important Software for Molecular Biology. GERF Bull. Biosci. 2011, 2, 60-61.

140. Kumar, S.; Stecher, G.; Tamura, K. MEGA7: Molecular Evolutionary Genetics Analysis Version 7.0 for Bigger Datasets. Mol. Biol. Evolution. 2016, 33, 1870-1874. [CrossRef] [PubMed]

141. Goodfellow, M.; Fiedler, H.-P. A Guide to Successful Bioprospecting: Informed by Actinobacterial Systematics. Antonie Van Leeuwenhoek 2010, 98, 119-142. [CrossRef] [PubMed]

142. Khattab, A.I.; Babiker, E.H.; Saeed, H.A. Streptomyces: Isolation, Optimization of Culture Conditions and Extraction of Secondary Metabolites. Int. Curr. Pharm. J. 2016, 5, 27-32. [CrossRef]

143. Pang, Z.Q.; Chen, J.; Wang, T.H.; Gao, C.S.; Li, Z.M.; Guo, L.T.; Xu, J.; Cheng, Y. Linking Plant Secondary Metabolites and Plant Microbiomes: A Review. Front. Plant Sci. 2021, 12, 300. [CrossRef] [PubMed] 